IRSH 62 (2017), pp. I-35 doi:10.10I7/S00208590I600065 I

(C) 2017 Internationaal Instituut voor Sociale Geschiedenis

\title{
Justice for Janitors Goes Dutch. Precarious Labour and Trade Union Response in the Cleaning Industry (I988-2012): A Transnational History*
}

\section{A D K NOTTER}

\section{Sociaal-Historisch Centrum voor Limburg, Maastricht University Sint Pieterstraat 7, 62 I I JM Maastricht, The Netherlands}

\author{
E-mail: a.knotter@maastrichtuniversity.nl
}

Making my way through the entrance hall, I cannot keep my eyes off the spotless, shiny marble floor, that seems to reflect an intention of presenting the kind of glamour and pace of economic dynamism that the management here takes such pride in. But the story isn't all that flashy. ${ }^{\mathrm{I}}$

SEIU is going to change the world. We are changing the world, for workers anyway [...] Look, we started in LA, we picked it up in London [...] Look at the Netherlands, it's amazing what we have been able to do there. They were getting their asses kicked and now they're running campaigns. ${ }^{2}$

AвSTRACT: Precarious labour has been on the rise globally since the i970s and i980s. Changing labour relations in the cleaning industry are an example of these developments. From the I970s onwards, outsourcing changed the position of industrial cleaners fundamentally: subcontracting companies were able to reduce labour costs

\footnotetext{
* The title is borrowed from Heather Connolly et al., “Justice for Janitors' Goes Dutch: The Possibilities and Limitations of an Organising Approach in the Netherlands for a Sustained Union Renewal", unpublished paper given at the British Universities Industrial Relations Association Conference, 7-9 July 20I I, University of Greenwich, London, available at: https://www2.warwick.ac. $\mathrm{uk} / \mathrm{fac} / \mathrm{soc} / \mathrm{wbs} / \mathrm{research} / \mathrm{irru} /$ publications/recentconf/hc_buira_20II.pdf. All internet sources for this article were consulted between December 2015 and April 2016. My research was greatly helped by conversations with Mari Martens, Ron Meyer, and Eddy Stam, who were responsible for the FNV Bondgenoten cleaners' campaigns in the Netherlands, and with the Maastricht cleaner-activist Tim Edwards. FNV Bondgenoten documentalist Irma van den Bosch provided valuable material. I would also like to thank my honours students Erica Belcher, David Darler, Lisa Hermanns, and Raoul Müller for their engagement and lively discussions.

I. Hsiao-Hung Pai, "The Invisibles: Migrant Cleaners at Canary Wharf”, Feminist Review, 78:I (2004), pp. I64-I74, I64.

2. Valery Alzaga, a Justice for Janitors organizer for the Service Employees International Union (SEIU), interviewed (2010) in Jamie K. McCallum, Global Unions, Local Power: The New Spirit of Transnational Labor Organizing (Ithaca, NY and London, 20I3), p. 48. For a thirty-minute interview with Alzaga on organizing tactics and her involvement in Holland, see https://snuproject. wordpress.com/2014/02/21/organizing-the-unorganizable-justice-for-janitors-an-interview-withvalery-alzaga/.
} 
by recruiting mainly women and immigrants with a weak position in the labour market. For trade unions, it was hard to find a way to counteract this tendency and to organize these workers until the Justice for Janitors $(\mathrm{J} 4 \mathrm{~J})$ campaigns, set up by the US-based Service Employees International Union (SEIU) from the late I980s, showed that an adequate trade union response was possible. From the mid-2000s, the SEIU launched a strategy to form international coalitions outside the US. It met a favourable response in several countries. In the Netherlands, a campaign modelled on the $\mathrm{J}_{4} \mathrm{~J}$ repertoire proved extraordinarily successful. In this article, transnational trade unionism in the cleaning industry based on the $\mathrm{J}_{4} \mathrm{~J}$ model will be analysed with a special focus on the Dutch case. How were local labour markets and trade union actions related to the transnational connections apparent in the rise of multinational cleaning companies, the immigrant workforce, and the role of the SEIU in promoting international cooperation between unions?

To the surprise of many observers accustomed to industrial harmony in the Netherlands - epitomized in the so-called poldermodel - low-paid and, until then, mostly unorganized cleaners staged successful strikes in 2010, 20I2, and 20I4, with the full support of the Dutch trade union FNV Bondgenoten. As a result of these strikes, the cleaners achieved considerable improvements in collective agreements with the cleaning companies. Only insiders knew that these strikes had been carefully prepared and planned by FNV Bondgenoten in close cooperation with the US-based Service Employees International Union (SEIU), ${ }^{3}$ and modelled on the example of the SEIU campaign Justice for Janitors since the late I980s. ${ }^{4}$ In this campaign, SEIU had developed a new approach to organizing by hiring a cadre of specialist organizers other than general union officers. ${ }^{5}$ The SEIU had been successful in the Justice for Janitors campaigns because of tactics based on the active involvement of newly recruited members. Following this approach, FNV Bondgenoten encouraged self-organization and the formation of leaders at workplace level. Through a combination of

3. Dutch newspapers reported on the US connection, but it was not known to the public: Esther Bijlo, "Nieuw: De Doe-het-zelf-actie", Troww, i7 April 2010; Jurry Brand and Jarco de Swart, "Vakbond terug naar winderige werkplek", De Telegraaf, 24 April 20ı; Elsbeth Stoker, "Organizer is de spin in het web van de stakingsactie", de Volkskrant, 27 May 2010.

4. "Janitor" is American-English for "cleaner". Originally, a janitor was a concierge, for whom cleaning was only part of his job: Raymond L. Gold, "In the Basement: The Apartment Building Janitor", in Peter L. Berger (ed.), The Human Shape of Work: Studies in the Sociology of Occupations (New York, 1964), pp. I-49. The research for this article was done in 1949/1950. In light of the following, it is remarkable that, according to this author (p. 4I), "Men become janitors, and stay on as janitors, to enjoy economic security".

5. Stephen Lerner, "Let's Get Moving: Labor's Survival Depends on Organizing Industry-Wide for Justice and Power", Labor Research Review, I:I 8 (I99I), pp. I-I 5. Lerner was the SEIU's architect of the Justice for Janitors campaign. 
grass-roots organizing, direct action, and broad coalitions the union was able to put pressure on subcontracting cleaning companies and their clients.

In spite of the evidently top-down start of the campaign by FNV Bondgenoten, the organizing model was meant to connect the union with its grass roots by developing focused recruitment campaigns in a bottom-up approach. The cleaners themselves had to be mobilized for active involvement in actions and negotiations. For Ron Meyer, responsible for organizing the campaign on behalf of FNV Bondgenoten, trade-union renewal was at the heart of his endeavours:

For too long the union has viewed its members as consumers, and that hasn't encouraged them to get involved. In my view, the image of the union leader shepherding his flock is dead and gone. People have to be clued up on their situation, because they are the only ones who can get things done. Only they can stick up for their rights and go on the front foot. ${ }^{6}$

In my view, these developments have a broader meaning than just the successes of FNV Bondgenoten in mobilizing the cleaners in strikes and other actions to improve working conditions. What is at stake is the ability of lowpaid, precarious workers to stand up for their collective rights in an increasingly individualized, flexible, and unfavourable labour market. ${ }^{7}$ The debate on precarious labour and its origins in the neoliberal restructuring of labour markets since the I 980 s has been going on for some time. The cleaning industry is an example of these developments. Social scientists have been studying professional cleaning precisely because "it is paradigmatic for the whole low-skilled service sector in many respects". ${ }^{8}$ Cleaners used to be part of the labour force in public institutions, manufacturing, banking, transport, and other services, and were covered by collective agreements in these industries. From the I 980 s, outsourcing changed the position of cleaners fundamentally: increasingly, they were employed by specialized companies in a separate industry, which continued to grow in an extremely competitive market for cleaning services. In the labour-intensive cleaning industry, reducing labour costs was considered the only way to secure contracts. Subcontracting companies were able to do so by recruiting mainly women and immigrants with a weak position in the labour market. The cleaners' actions, both in the Netherlands and elsewhere in the world, showed that an

6. Cited in Pien Heuts, “No More Being Ground Down for Us'. Dutch Cleaners Up in Arms”, HesaMag, 2 (2010), pp. 27-3 I 28-29. See also idem, Tegenmacht (Utrecht, 20I I); Diederik Olders and Sjaak van der Velden, Respect! De staking van de schoonmakers in 2010 (Rotterdam, $201 \mathrm{I}$ ). 7. Merijn Oudenampsen, "Precariousness in the Cleaning Business: Cleaners as the Vanguard of a New Trade Union Revival”, Open! Platform for Art, Culture and the Public Domain (2009), available at: www/onlineopenorg/precariousness-in-the-cleaning-business.

8. Nicole Mayer-Ahuja, “Three Worlds of Cleaning: Women's Experiences of Precarious Labor in the Public Sector, Cleaning Companies and Private Households of West Germany, 1973-1998", Journal of Women's History, I6:2 (2004), pp. I I6-I4I, I I6. 
adequate trade union response was possible to counteract this seemingly inevitable tendency towards precariatization of the labour force. ${ }^{9}$

During the Justice for Janitors campaigns in the United States, the SEIU discovered that, although operating in highly competitive local markets for place-bound cleaning services, subcontracting firms were often part of large multinationals. ${ }^{10}$ An example is International Service Systems (ISS Facility Services), one of the largest cleaning companies in the US and, in fact, the world. It originates from, and is based in Denmark, but operates on a global scale. ${ }^{\text {II }}$ In 2004, the SEIU concluded that "many members worked for companies that were multinational. To win members' contracts, we had to campaign at a multinational level". ${ }^{22}$ At its 2004 Convention, the SEIU launched a strategy to form sustained international coalitions. Exploratory visits were made to several countries in order to select unions for partnership. The union invested significant resources in regional officers and organizers in Australia, Britain, the Netherlands, and other countries. Membership and leadership exchanges were organized to set up campaigns. ${ }^{\mathrm{I} 3}$ One of the aims was to get multinational employers and their clients to sign on to socially responsible contractor global agreements. Union Network International (UNI, now UNI Global Union), the global union federation for services, succeeded in signing such a contract with ISS as a framework for national branches to negotiate with cleaners' unions. ${ }^{I 4}$ Cooperation with FNV Bondgenoten was thus part of a deliberate strategy by the SEIU to transnationalize trade unionism in the cleaning sector. Comparable campaigns were set up with partners in London ("Justice for Cleaners"), in Australia and New Zealand ("Clean Start"), and on a smaller scale, partly inspired by the Dutch example, in Germany ("Ich putze Deutschland"). ${ }^{15}$

9. Valery Alzaga, "Justice for Janitors Campaign: Open-sourcing Labour Conflicts against Global Neo-liberalism", OpenDemocracy, 7 February 20I I, available at: https://www.opendemocracy.net/ valery-alzaga/justice-for-janitors-campaign-open-sourcing-labour-conflicts-against-global-neo-libera. Io. Stephen Lerner, "Global Corporations, Global Unions", Contexts, 6:3 (2007), pp. 16-22, reprinted in Jeff Goodwin and James M. Jasper (eds), The Social Movements Reader: Cases and Concepts (Chichester, 2009), pp. 364-371.

I I. In 2004, it operated in forty-three countries, with more than 200,000 employees worldwide: Stephen Lerner, "Global Unions: A Solution to Labor's Worldwide Decline”, New Labor Forum, I6: I (2007), pp. 22-37, 29 (based on ISS Annual Report 2004). See also http://www.issworld.com/. I 2. SEIU vice-president Tom Woodruff, cited by Amanda Tattersall, "Labor-Community Coalitions, Global Union Alliances, and the Potential of SEIU's Global Partnerships", in Kate Bronfenbrenner (ed.), Global Unions: Challenging Transnational Capital Through Cross-Border Campaigns (Ithaca, NY and London, 2007), pp. I55-173, I6I.

I 3. Ibid., p. I67; Louis L.M. Aguiar and Shaun Ryan, "The Geographies of the Justice for Janitors", Geoforum, 40:6 (2009), pp. 949-958, 952.

I4. Personal communication from Mari Martens, 5 February 20I6, and Eddy Stam, is April 2016; Alzaga, "Justice for Janitors Campaign”. See also http://www.ewcdb.eu/docs/923 I.

I s. Natale Fontana, "A Comparative Analysis on Trade Union Approaches to Precarious Work in the Cleaning Sector using Examples of the US, Germany and the Netherlands" (MA, Berlin 
This article aims to analyse transnational trade unionism in the cleaning industry between the start of the Justice for Janitors campaign in Los Angeles in 1988 and the Dutch cleaners' strike in 2012 in the context of the debate on precariousness and neoliberal restructuring of labour markets since the I980s. By developing new forms of organizing, the SEIU, followed by trade unions in the Netherlands, Britain, Australia, and elsewhere, found ways to combat the effects of the restructuring of cleaning services on local and national labour markets. How were these local labour markets and trade union actions related to the transnational connections apparent in the rise of multinational cleaning companies, the immigrant workforce, and the role of the SEIU in promoting international cooperation between unions? Or, to put it in more fashionable terms, how was the "local" connected to the "global"? A comparison of campaigns in Los Angeles, London, Australia, and Canada, and a more detailed analysis of the Dutch case, will show that ultimately the transnationalism of cleaners' unionism had its limits: the example set by Justice for Janitors in the US and the support of the SEIU helped in getting campaigns off the ground, but in the end unions had to act locally or nationally to force employers to accept a regulation of wages and working conditions.

After a general introduction to precariousness and the trade union response to labour-market restructuring and its impact on the cleaning industry since the I 970 and I 980 , these issues will be researched firstly by analysing developments in Los Angeles, where the Justice for Janitors campaigns in the I990s had inspired not only filmmaker Ken Loach to produce the award-winning feature film Bread and Roses, but also "a mountain of academic studies", ${ }^{16}$ which could be used for analysing the Los Angeles case. Then I will describe the export of the Justice for Janitors model to the rest of the US, Britain, Australia / New Zealand, and Canada. Finally, I will focus on the cleaners' strikes in the Netherlands to see whether what we found out about the cleaners' actions in Los Angeles and elsewhere can be helpful in understanding the Dutch case.

\section{PRECARIOUS LABOUR AND TRADE UNION RESPONSE}

The concept of precariousness entails instability, lack of protection, insecurity, and economic vulnerability. Precarious work can be defined as

School of Economics and Law, 20I 2), pp. 55-68, available at: https://opus4.kobv.de/opus4-hwr/ frontdoor/index/index/docId/49; Peter Bremme, Ulrike Fürniß, and Ulrich Meinecke (eds), Never Work Alone: Organizing - ein Zukunftsmodell für Gewerkschaften (Hamburg, 2007); Kurt Vandaele and Janine Leschke, "Following the 'Organising Model' of British Unions? Organising Non-standard Workers in Germany and the Netherlands", European Trade Union Institute (ETUI), Working Paper 2010.02 (ETUI, 2010), available at: https://www.etui.org/Publications2/ Working-Papers/Following-the-organising-model-of-British-unions.

16. McCallum, Global Unions, Local Power, p. 49. 


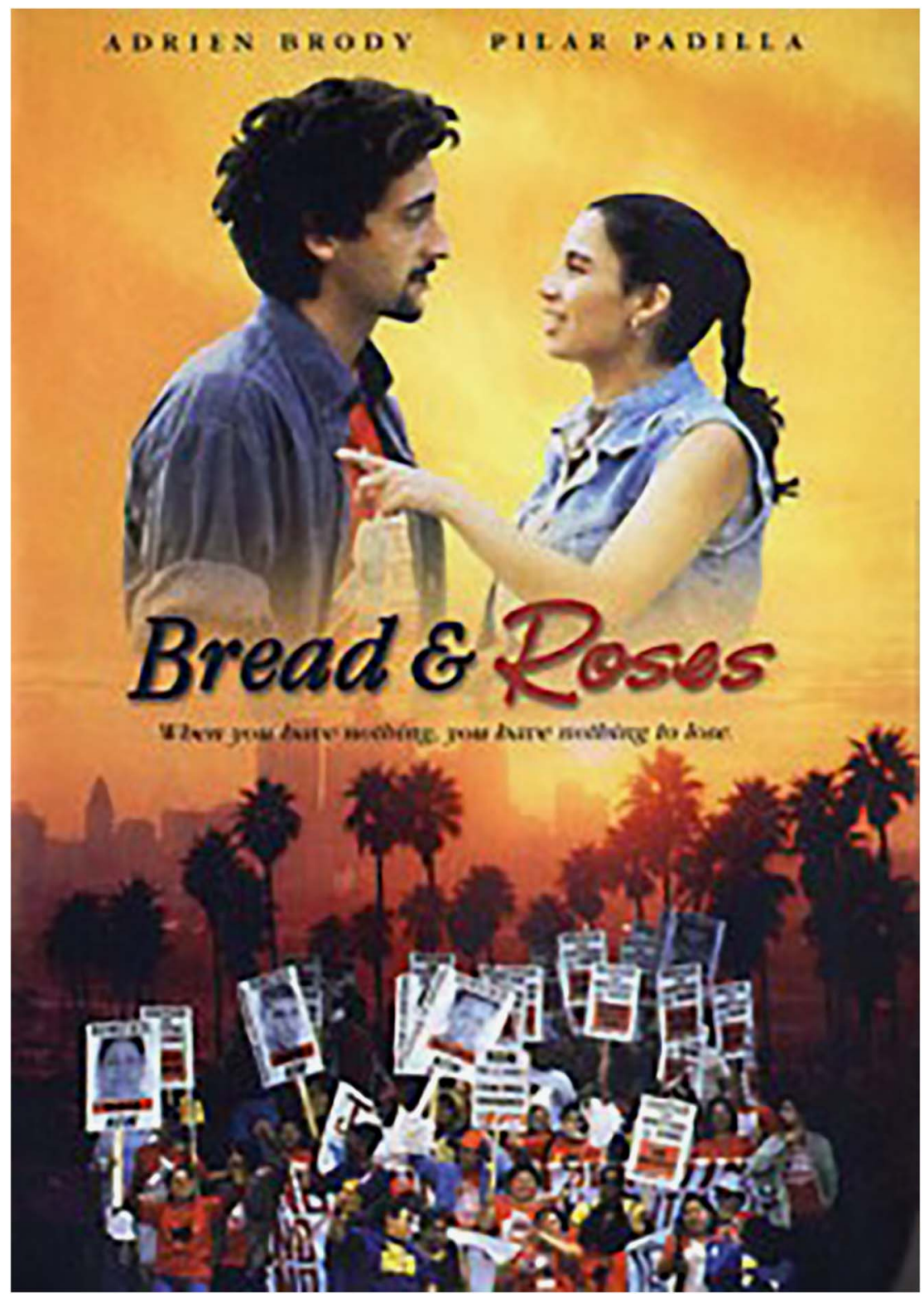

Figure I. Film poster of Bread E Roses, the movie about Justice for Janitors in Los Angeles by Ken Loach, produced by Rebecca O’Brien, and written by Paul Laverty (2000). Used with permission of Sixteen Films. 
uncertain, unpredictable, risky, and low paid. As such, precarious employment is not new: it has been an integral part of the experience of wage labour, both historically and globally. To reduce uncertainty in the labour market, the trade union movement tried, from its origins in the nineteenth century, to conclude collective agreements to regulate employment relations, and demanded social security measures and protective labour laws from the state. During the phase of steady economic growth between the end of World War II and the mid-I970s, forms of labourmarket regulation and protection of regular jobs came to dominate the industrial system in Western or Westernized capitalist countries. Full-time, permanent, on-site waged employment became the "standard employment relation", albeit predominantly for the male part of the workforce.

Since the last quarter of the twentieth century, however, the full-time permanent jobs that were the hallmark of economic growth after World War II have been in decline. Everywhere, there is a shift towards flexible labour, part-time jobs, fixed-term contracts, self-employment by nominally independent contractors, and temporary or agency work, producing an increasing precariousness of employment. ${ }^{17}$ The erosion of the standard employment relation since the economic crisis of the mid-1970s was a consequence of increasingly competitive pressures on companies in globalizing markets to reorganize in more flexible ways. As a result, employment relations became more diverse. Former ILO official Guy Standing even detected a new, separate class of precarious workers, to which he applied the neologism "precariat" (from "precarious" and "proletariat"). ${ }^{18}$ These developments have been underpinned by neoliberal approaches in socioeconomic regulation and policymaking.

Historically, trade unions have been important in the drive towards labour-market regulation and social protection. Conversely, the growth of precarious labour in the last quarter of the twentieth century was closely

17. Carole Thornley, Steve Jefferys, and Beatrice Appay (eds), Globalization and Precarious Forms of Production and Employment: Challenges for Workers and Unions (Cheltenham, 2010); Arne L. Kalleberg, Good Jobs, Bad Jobs: The Rise of Polarized and Precarious Employment Systems in the United States, I970s to 2000 s (New York, 201 I), pp. 24-26. See also Arne L. Kalleberg, "Precarious Work, Insecure Workers: Employment Relations in Transition", American Sociological Review, 74: I (2009), pp. I-22.

I8. Guy Standing, The Precariat: The New Dangerous Class (London, 201 I). For a critique, see Erik Olin Wright, Understanding Class (London, 2015), ch. 9; see also idem, "Is the Precariat a Class?", Global Labour Journal, 7:2 (2016), pp. I23-135. The neologism précariat to designate people in a precarious position as a specific social group or "class" originated in France: François Schreuer, “Qu'est-ce-que le précariat?", Politique. Revue de débats, 46 (2006) [Thème. "Le précariat, entre contrainte et liberté"]. See also Jean-Claude Barbier, "La précarité, une catégorie française à l'épreuve de la comparaison internationale", Revue française de sociologie, 46 (2005), pp. 35 I-37I. For a recent evaluation, see Donatella della Porta et al. (eds), The New Social Division: Making and Unmaking Precariousness (Basingstoke, 2015). 
related to the weakening of trade unions in that period, expressed both in terms of union membership and density. Insecurity in its various manifestations increased because the protective shield of trade unionism was removed. ${ }^{I 9}$ Some, however, tend to blame the unions themselves for this decline, because of their inability to organize and represent the "precariat". In this view, the trade union movement only represents core workers, whose numbers are declining and whose interests are fundamentally different from those of precarious workers. ${ }^{20}$ In some countries, particularly in Italy, Spain, and France, precarity is used to mobilize people outside union organizing and beyond the workplace. When work is constantly changing, so the argument goes, it makes little sense to organize around it. ${ }^{2 \mathrm{I}}$

Nevertheless, trade unions are becoming increasingly aware of the dangers of deregulation and flexibilization of labour markets, also for core workers. For Europe, this is becoming apparent from the reports of the EU-funded research projects "Bargaining for Social Rights" (BARSORI), and its sequel "Bargaining for Social Rights at a Sectoral Level" (BARSORIS), coordinated by the Amsterdam Institute for Advanced Labour Studies (University of Amsterdam). ${ }^{22}$ European unions have begun serious efforts to extend trade unionism to the insecure workforce, to recruit "outsiders" with precarious, low-paid jobs, with the aim of improving their employment conditions. ${ }^{23}$ Of special interest in the context of the cleaners' campaigns are attempts to recreate trade unions as social movements, with the purpose of mobilizing members and supporters against injustice at work. In a number of cases, organizing workers in precarious jobs in this way has worked quite well. ${ }^{24}$ The BARSORI and BARSORIS country reports on the UK, the Netherlands, and Germany all invoke the campaigns to mobilize cleaners as examples of attempts at organizing precarious workers.

19. Edmond Heery and Brian Abbott, "Trade Unions and the Insecure Workforce", in Edmond Heery and John Salmon (eds), The Insecure Workforce (London, 2000), pp. I 55-180. On the US, see Kalleberg, Good Jobs, Bad Jobs, pp. 3 I-34.

20. This seems to be Standing's position: Guy Standing, A Precariat Charter: From Denizens to Citizens (London, 2014).

2r. Dennis Arnold and Joseph R. Bongiovi, "Precarious, Informalizing, and Flexible Work: Transforming Concepts and Understandings", American Behavioral Scientist, 57:3 (2013), pp. 289-308, 299.

22. Reports on both projects for each country (Denmark, Germany, Italy, the Netherlands, Slovakia, Spain, United Kingdom) can be found on the project websites. BARSORI: http:// archive.uva-aias.net/36I and BARSORIS: http://archive.uva-aias.net/426.

23. Maarten Keune, "Trade Union Responses to Precarious Work in Seven European Countries", International Journal of Labour Research, 5:I (2013), pp. 59-78, 66; idem, "Trade Unions, Precarious Work and Dualisation in Europe", in Werner Eichhorst and Paul Marx (eds), Non-Standard Employment in Post-Industrial Labour Markets: An Occupational Perspective (Cheltenham, 2015), pp. 378-400.

24. Heery and Abbot, "Trade Unions and the Insecure Workforce”, pp. 163-170. 


\section{SUBCONTRACTING, CLEANING, AND PRECARIOUSNESS: A GLOBAL DEVELOPMENT}

Studies on the development of the cleaning industry in a range of countries invariably show that since the I970s/1980s outsourcing has resulted in an increasing number of jobs in subcontracting firms subject to competitive tendering. The process of tendering caused insecurity of employment as well as a potential reduction in wages and entitlements. For subcontracting firms, the key issue was to retain and increase the number and size of contracts. The costs of labour and the conditions under which it was employed were crucial elements in the bidding process. Periodic reviews of terms and conditions of contracting generated uncertainty about future work relationships and the spread of precarious employment.

The shift to contracting out cleaning to specialized companies in the last quarter of the twentieth century and its deteriorating effects on working conditions have been documented for Israel, ${ }^{25}$ the US, ${ }^{26}$ Great Britain, ${ }^{27}$ Canada, ${ }^{28}$ Australia and New Zealand, ${ }^{29}$

25. Deborah Bernstein, "The Subcontracting of Cleaning Work in Israel: A Case in the Casualisation of Labour", The Sociological Review, 34:2 (1986), pp. 396-422.

26. John Howley, "Justice for Janitors: The Challenge of Organizing in Contract Services", Labor Research Review, I:Is (1990), pp. 6I-7I; Richard Mines and Jeffrey Avina, "Immigrants and Labor Standards: The Case of California Janitors", in Jorge A. Bustamente, Clark W. Reynolds, and Raúl A. Hinojosa Ojeda (eds), US-Mexico Relations: Labor Market Interdependence (Stanford, CA, 1992), pp. 429-448; Cynthia Cranford, "Gender and Citizenship in the Restructuring of Janitorial Work in Los Angeles", Gender Issues, I6:4 (I998), pp. $25-5$ I; idem, "Economic Restructuring, Immigration and the New Labor Movement: Latina/o Janitors in Los Angeles”, Working Paper No. 9, Center for Comparative Immigration Studies, University of California, San Diego, 2000.

27. Angela Coyle, "Going Private: The Implications of Privatization for Women's Work", Feminist Review, 2 I (1985), pp. 5-23; Gareth Rees and Sarah Fielder, "The Services Economy, Subcontracting and the New Employment Relations: Contract Catering and Cleaning”, Work, Employment and Society, 6:3 (1992), pp. 347-368; John Allen and Nick Henry, "Ulrich Beck's Risk Society at Work: Labour and Employment in the Contract Service Industries", Transactions of the Institute of British Geographers, 22:2 (1997), pp. 180-196; idem, "Fragments of Industry and Employment: Contract Service Work and the Shift Towards Precarious Employment", in Rosemary Crompton, Duncan Gallie, and Kate Purcell (eds), Changing Forms of Employment: Organisations, Skills and Gender (London, I996), pp. 65-82; Jane Wills, "Making Class Politics Possible: Organizing Contract Cleaners in London", International Journal of Urban and Regional Research, 32:2 (2008), pp. 305-323.

28. Luis L.M. Aguiar, "Restructuring and Employment Insecurities: The Case of Building Cleaners", Canadian Journal of Urban Research, 9: I (2000), pp. 64-93.

29. Peter Brosnan and Frank Wilkinson, "Low Pay and Industrial Relations: The Case of Contract Cleaning", New Zealand Journal of Industrial Relations, I4:I (I989), pp. 83-89; Shaun Ryan and Andrew Herod, "Restructuring the Architecture of State Regulation in the Australian and Aotearoa/New Zealand Cleaning Industries and the Growth of Precarious Employment", Antipode: A Radical Journal of Geography, 38:3 (2006), pp. 486-507; Iain Campbell and Manu Peeters, "Low Pay, Compressed Schedules and High Work Intensity: A Study of Contract Cleaners in Australia”, Australian Journal of Labour Economics, I I: (2008), pp. 27-46; Sasha Holley and Al 
Germany, ${ }^{30}$ France, ${ }^{31}$ Belgium, ${ }^{32}$ and other countries. ${ }^{33}$ Everywhere, there has been an increase in outsourcing to a growing number of cleaning companies. The organization of employment in these companies is based on a quest for maximum flexibility. Subcontracting enhances the competition among companies and results in a race to the bottom of production costs. To find people prepared to work in these conditions, the cleaning sector has to draw its workforce from the most vulnerable segments of the labour force: female and migrant workers are hugely overrepresented in every country. However, for these people, to find a job in the cleaning sector can also be a means to gain access to the labour market, and even a starting point of emancipation by collective action. That is the story of the predominantly Latino and Latina janitors in Los Angeles in the I980s and I990s. Their keen desire for economic advancement made them ready to act collectively, once offered opportunities to do so.

\section{LESSONS FROM LA}

Latino rank-and-file workers have made the Los Angeles area the major R\&D center for 2 Ist-century trade unionism. ${ }^{34}$

Contemporary observers considered the Justice for Janitors campaign in Los Angeles "the single most important organizing success of the US labour movement in the late twentieth century". ${ }^{35}$ Led by union organizers sent by

Rainnie, "Who Cleans Up? The Declining Earnings Position of Cleaners in Australia", The Economic and Labour Relations Review, 23:I (2012), pp. I43-160.

30. Mayer-Ahuja, "Three Worlds of Cleaning".

31. Lorenzo Munar Suard and Guy Lebeer, "Nature et contenus de la relation de sous-traitance dans le secteur du nettoyage", Travail Emploi Formation, 6 (2006), pp. 6-31; Jean-Michel Denis, "Dans le nettoyage, c'est le chantier qui part en grève", in S. Béroud and P. Bouffartigue (eds), Quand le travail se précarise, quelles résistances collectives? (Paris, 2009), pp. 99-1 16, 100-10I; Heather Connolly, "Organizing and Mobilizing Precarious Workers in France: The Case of Cleaners in the Railways", in Thornley et al., Globalization and Precarious Forms of Production and Employment, pp. I 82-198; Cristina Nizzoli, C'est du propre! Syndicalisme et travailleurs $d u$ "bas de l'échelle" (Marseille et Bologne) (Paris, 2016).

32. Marianne De Troyer, Guy Lebeer, and Esteban Martinez, "La précarité des ouvrières du nettoyage en Belgique. Des réponses collectives à la dérégulation", Travail, genre et sociétés, 29:I (20I3), pp. 87-IO4.

33. For a comprehensive overview see Luis L.M. Aguiar and Andrew Herod (eds), The Dirty Work of Neoliberalism: Cleaners in the Global Economy (Oxford, 2006) [also as a Special Issue of Antipode: A Radical Journal of Geography, 38:3 (2006), pp. 425-666].

34. Mike Davis, Magical Urbanism: Latinos Reinvent the US City (London and New York, 200I), p. I70; see also Ruth Milkman, LA Story: Immigrant Workers and the Future of the US Labor Movement (New York, 2006).

35. Christopher L. Erickson et al., "Justice for Janitors in Los Angeles: Lessons from Three Rounds of Negotiations", British Journal of Industrial Relations, 40:3 (2002), pp. 543-567, 544; 
SEIU headquarters in Washington DC, the campaign was set up in I988, following earlier successful rallies of this kind in Denver (1986) and Washington DC (1987). ${ }^{36}$ It relied on a variety of unorthodox tactics designed to put pressure on owners and managers of client companies, also by mobilizing bystanders and sympathizers from the broader community. In 1989 , the union decided to focus on a large, newly built office complex in Los Angeles, called Century City, employing 400 janitors, of whom 250 were with the cleaning contractor ISS. In May I990, a strike was called, and not long after a contract was signed with the largest cleaning companies ISS and ABM, later to be extended to smaller firms. A second round of negotiations took place in 1995. The result was a five-year agreement. With contract renewal in 2000 in sight, the SEIU local began to prepare its members for mass protests by "internal organizing”. A strike in April was accompanied by dramatic street protests, daily rallies in public places, and efforts to get media attention and put pressure on major players in the industry. Again, the big cleaning companies proved willing to concede, and overruled the more intransigent smaller firms. The strike was settled at the end of its third week, in a widely-celebrated victory for the union. The new three-year contract included a twenty-five per cent pay raise as well as greatly improved health benefits. In the 2003 contract, the SEIU's janitors made still further gains, this time without a strike. Between I988 and I995, the SEIU organized over 8,000 janitors in LA; ${ }^{37}$ the settlement in 2000 added another $5,000 .^{38}$

idem, "Justice for Janitors in Los Angeles and Beyond: A New Form of Unionism in the TwentyFirst Century?", in Phanindra V. Wunnava (ed.), The Changing Role of Unions: New Forms of Representation (New York, 2004), pp. 22-58; Amy Bridges, "The Sun Also Rises in the West", in Dennis R. Judd and Dick Simpson (eds), The City, Revisited: Urban Theory from Chicago, Los Angeles, and New York (Minneapolis, MN, 20II), pp. 79-103; Roger Waldinger et al., "Helots No More: A Case Study of the Justice for Janitors Campaign in Los Angeles", in Kate Bronfenbrenner et al. (eds), Organizing to Win: New Research on Union Strategies (Ithaca, NY, 1998), pp. 102-1 I9.

36. Stephen Lerner, Jill Hurst, and Glenn Adler, "Fighting and Winning in the Outsourced Economy: Justice for Janitors at the University of Miami", in Annette Bernhardt et al. (eds), The Gloves-off Economy: Workplace Standards at the Bottom of America's Labor Market (Champaign, IL, 2008), pp. 243-267, 249; Jane Williams, "Restructuring Labor's Identity: The Justice for Janitors Campaign in Washington D.C.”, in R. Tillman and M. Cummings (eds), The Transformation of US Unions: Voices, Visions, and Strategies from the Grassroots (Boulder, CO, 1999), pp. 203-2 17. For a digital history of Justice for Janitors in Washington DC, see http://www. georgetownlaborhistory.org/.

37. Cynthia Cranford, "Labor, Gender and the Politics of Citizenship: Organizing Justice for Janitors in Los Angeles" (Ph.D., University of Southern California, 200I), p. I35; idem, "Gendered Resistance: Organizing Justice for Janitors in Los Angeles", in J. Stanford and L. Vosko (eds), Challenging the Market: The Struggle to Regulate Work and Income (Montreal, 2004), pp. 309-329, 3 I 8.

38. Milkman, LA Story, p. I60. 


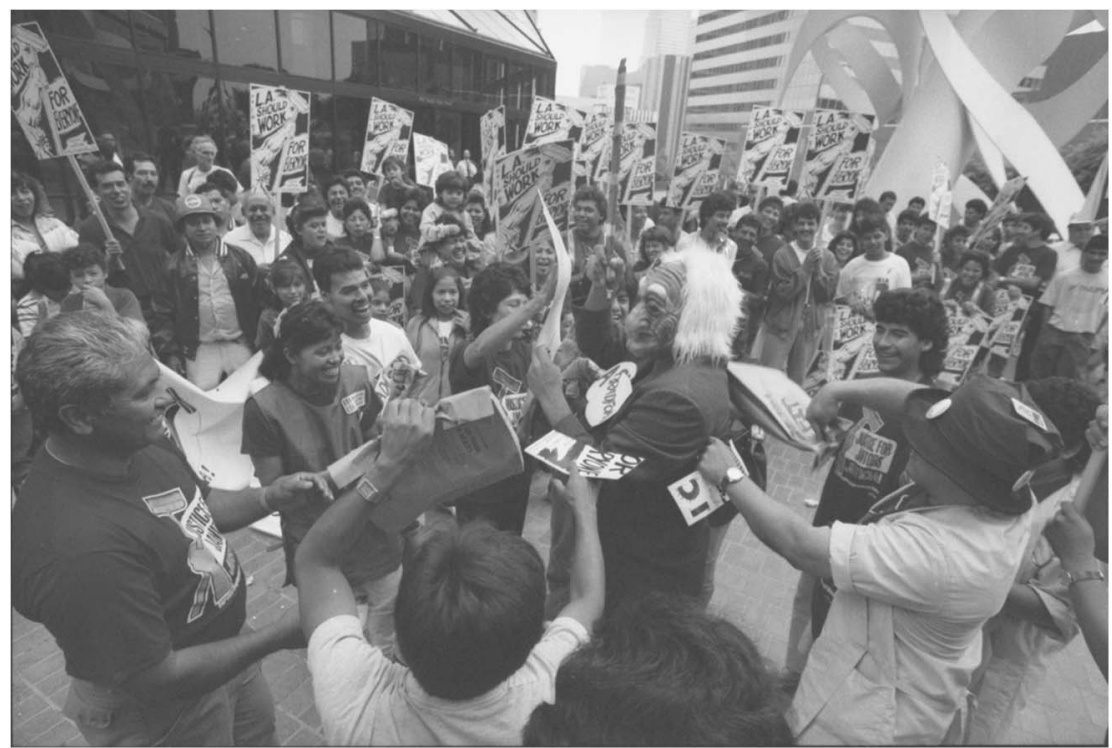

Figure 2. Downtown rally by Justice for Janitors in Los Angeles 1990: "Union demonstrators who marched around the downtown high rise buildings where they rallied for better contracts, end with skit of character of a greedy contractor who pays poor wages for cleaning services".

Source: UCLA Library Special Collections. Los Angeles Times photo archive Coll. I429. Photograph by Mike Sergieff.

Justice for Janitors unionism was constructed as a broader politics of social justice for the community as a whole. By legal action, symbolic representation, and direct confrontation in street protests, the campaign was targeted at building owners, to press them to take responsibility for the welfare of janitors who were formally employed by the cleaning contractors. To bring their otherwise invisible presence into the open, groups of protesting cleaners and their allies occupied public spaces (streets, intersections, and pavements), picketed building entrances, and invaded properties of building owners. Public appearances were accompanied by speeches, flyers, street theatre, and other means of symbolic communication. Publicity stunts staged to draw attention to the janitors' plight were highly effective in publicly embarrassing powerful players in the industry, while also making life difficult for building tenants. ${ }^{39}$ The cleaners' cause was presented as an issue of social justice for the underprivileged in general, in contrast to the privileges and the wealth of the owners and occupiers of the glittering high-rise offices where they did their job. In this way, they 
were able to garner sympathy and moral support from the wider community, religious leaders, and politicians. ${ }^{4}$

Mass mobilization combined with labour, religious, and political support pressed the building owners to call upon contractors to negotiate with the union and reach an agreement. While this kind of "symbolic power" may have been an effective avenue for the low-skilled cleaners with limited structural power in the labour market of their own, ${ }^{4 \mathrm{I}}$ its widespread use in the Justice for Janitors campaign is not enough to explain the willingness of the cleaning companies to concede. In LA Story, her account of the city's trade union history, Ruth Milkman draws attention to the tradition of the American Federation of Labor (AFL), to which the SEIU belonged, of "regulatory unionism": AFL unions focused their organizing efforts on decentralized, highly competitive industries, with the aim of stabilizing local or regional labour markets in this industries by "taking wages out of competition". ${ }^{42}$ "Regulatory unionism" meant that unions put pressure on employers to recognize that strong unions and uniformly negotiated wages could serve as a means of regulating labour costs across an industry, especially in disorganized industries otherwise unable to achieve market stability. Strong unions and collective agreements were used to equalize labour costs and to discipline or eradicate marginal competitors. ${ }^{43}$

The Justice for Janitors campaign managed to restore labour-market regulation based on union power. To exercise union leverage on all key players in the local labour market so as to effectively take wages out of competition had been the explicit goal of Stephen Lerner, its key architect. ${ }^{44}$ The SEIU strived for arrangements whereby the local union could control the terms and conditions that would prevail across the local labour market as a whole. ${ }^{45}$ To realize this, the union tried to win companies willing to negotiate over to its side: after a contractor reached

40. Cranford, "Gendered Resistance”, pp. 320-323. The campaign also rallied support from wellknown UCLA academics, such as the geographers Mike Davis and Edward Soja, who encouraged their students to join and helped develop a new generation of union researchers: Alzaga, "Justice for Janitors Campaign”, p. 2.

4I. Jennifer Jihye Chun, Organizing at the Margins: The Symbolic Politics of Labor in South Korea and the United States (Ithaca, NY and London, 2009).

42. Milkman, LA Story, pp. 74-75. Industrial organizing by the Congress of Industrial Organizations (CIO, later to be merged with the AFL into the American trade union federation AFL$\mathrm{CIO}$ ) focused primarily on highly concentrated, oligopolistic industries (such as the automobile industry), where wage competition was not at issue. The term "regulatory unionism" was introduced by Colin Gordon, New Deals: Business, Labor, and Politics in America, 1920-1935 (New York, 1994).

43. Ibid., pp. 87-97.

44. Milkman, LA Story, pp. I 52, I 56; Lerner in Ruth Milkman and Kim Voss, "New Unity for Labor?", Labor: Studies in Working Class History of the Americas, 2: (2005), pp. I 5-25, I9.

45. Howley, "Justice for Janitors", p. 67. 
an agreement with the union, the SEIU would not raise wages until a majority of its competitors had decided to follow, ensuring that no contractor was put at a competitive disadvantage. ${ }^{46}$ This strategy forestalled the problem of making a union contractor uncompetitive in a market shaped by labour costs. No contractor was disadvantaged by the extra costs of higher wages and benefits. ${ }^{47}$

This strategy could be successful because cleaning as an economic activity is place bound and, despite being dominated by global corporations, largely immune from the effects of capital mobility. The large, global cleaning companies had to compete locally with small or medium-sized firms, which had easy access to the local market and could offer their services at lower costs (cleaning does not require large investments or specific skills). For this reason, the large companies had an interest in regulating the labour market by taking wages out of the competition. To put this into effect, however, they needed a strong union to enforce a contract that did just that. This explains the willingness of the larger firms to reach an agreement and force this upon the smaller ones in both the 1990 and 2000 campaigns. Moreover, for building owners, the costs of the settlement were marginal and for them it was easy to adapt the contracts once an industry-wide agreement had been reached.

All this had been deliberately aimed at in the Justice for Janitors campaign: the SEIU's strategists reasoned that, if agreement could be reached with the big players ABM and ISS, other smaller contractors would follow and LA's major office centres could be brought under a union contract. To enforce the willingness of the major contractors in the 2000 strike, however, the SEIU had to transcend the locality of the labour market and put pressure on their business elsewhere in the US by picketing buildings cleaned by these same companies in other cities. ${ }^{48}$ In what seemed to be a local affair, the union concluded that it could reach an agreement with the big cleaning companies more easily by turning to the grander scale of the national, and, some years later, the global.

\section{EXPORT OF THE JUSTICE FOR JANITORS MODEL}

Following the successes of the Los Angeles strikes, Justice for Janitors campaigns were launched in a range of cities around the US. The SEIU tried to raise standards for janitors by confronting owners and their contractors on a national basis. Campaigns routed contractors across the country,

46. Lerner, "Global Corporations, Global Unions", p. 338; Erickson et al., "Justice for Janitors in Los Angeles", p. 554.

47. Jennifer Luff, "Justice for Janitors", in Eric Arnesen (ed.), Encyclopedia of US Labor and Working-Class History, Volume I (New York and London, 2007), pp. 729-73 I, 730.

48. Erickson et al., "Justice for Janitors in Los Angeles", pp. 548, 554. 
winning sizable wage increases and health-care benefits. ${ }^{49}$ Its biggest victory was in Houston in 2006, in the heart of Republican and anti-union Texas, where the predominantly Latino immigrant janitors eventually secured a contract doubling their income and gaining health benefits after a month-long strike. ${ }^{\circ}$ In ten different cities across Europe and Latin America, the SEIU organized support for the Houston strike with allied unions and social movement organizations. ${ }^{5 \mathrm{I}}$

By then, the SEIU had already decided to go global, and the international solidarity campaign for the Houston strikers was part of its global action model. ${ }^{52}$ The SEIU sought to marshal a great number of allies in order to shape the terms of the global cleaning industry. After its "Global Strength" commitment at its 2004 national convention, a "global partnership unit" was founded by the union in November 2004, firstly to coordinate campaigns with a global scope, secondly to foster partnerships with unions in other countries to build global union power, and thirdly by providing experienced staff and support for organizing drives with partner organizations. ${ }^{53}$ Relationships were established through exploratory visits to other countries, including Australia, the United Kingdom, the Netherlands, and Germany, to discuss new forms of alliances and to find partners with a commitment to the organizing model. ${ }^{54}$ Many of the SEIU's global relationships (with the UK union Unite and FNV Bondgenoten, for example) began in the Union Network International (UNI), which was officially founded in 2000 following a merger of a number of international unions in the services' industry, and in which the SEIU played a prominent role. ${ }^{55}$

The SEIU chose to connect with unions that had already started or participated in organizing cleaners. In 2005, SEIU organizers were seconded to the British Transport \& General Workers Union (TGWU) to set up a Justice for Cleaners campaign in London, where financial companies at

49. For an overview, see Luff, "Justice for Janitors", to be supplemented by Lerner et al., "Fighting and Winning in the Outsourced Economy"; see also Preston Rudy, "Justice for Janitors,' not 'Compensation for Custodians': The Political Context and Organizing in San Jose and Sacramento", in Ruth Milkman and Kim Voss (eds), Rebuilding Labor: Organizing and Organizers in the New Union Movement (Ithaca, NY and London, 2004), pp. I33-I 49, and Jason Albright, "Contending Rationality, Leadership, and Collective Struggle: The 2006 Justice for Janitors Campaign at the University of Miami”, Labor Studies Journal, 33: ( 2008), pp. 63-80. 50. Glenn Edward Bracey, "Interracial Political Coalitions: An Analysis of Justice for Janitors Campaigns in Houston, TX” (M.Sc., Texas A\&M University, 2008), available at:http://oaktrust. library.tamu.edu/bitstream/handle/I969. I/ETD-TAMU-3247/BRACEY-THESIS.pdf? sequence=I. 5. Alzaga, "Justice for Janitors Campaign"; Lerner, "Global Corporations, Global Unions".

52. "Organise Local, Strike Global: Valery Alzaga Talks to Rodrigo Nunes about the Service Employees International Union's (SEIU) Global Organising Approach”, Turbulence: Ideas for a Movement, I (2007), available at: http://turbulence.org.uk/turbulence-I/organise-local-strike-global/.

53. Tattersall, "Labor-Community Coalitions", pp. I62-163.

54. Ibid., p. I67; Aguiar and Ryan, "The Geographies of the Justice for Janitors", p. 952.

55. McCallum, Global Unions, Local Power, pp. 70-71. 
Canary Wharf had already been targeted successfully. ${ }^{56}$ The arrival of SEIU strategists in 2005 prompted the TGWU to dramatically step up its campaign. A multilingual team of organizers, many of them ex-cleaners from Canary Wharf, was formed to work on the campaign, which extended to the Houses of Parliament and the City of London. By 2009, around 3,000 cleaners had been recruited as members of the union (now called Unite), and agreements were signed with the major cleaning contractors, including ISS. As in the US, migrants were hugely overrepresented among cleaners in London, and a remarkable $35-40$ per cent of participants in the London Justice for Cleaners campaign were Latin Americans. ${ }^{57}$

Like the one in Los Angeles, the London campaign was a clear example of "regulatory unionism". Drawing on the lessons of Justice for Janitors in the US, the TGWU tried to regulate the market by targeting the largest contractors across areas in a "zonal approach". Pay rises for around 4,000 cleaners across Canary Wharf and the City of London were to be met by the clients, and the union strategy was designed to prevent any retendering eroding the agreed terms and conditions. In the extremely competitive market for cleaning services, cleaning contractors recognized that they had a material interest in getting clients to pay more for good-quality cleaning, and that they were caught in a vicious cycle of competition that was not in their interest. As Jane Wills remarked in her analysis of the London campaigns, this situation provided fertile ground for the TGWU to develop relationships with parts of the cleaning industry and industry-wide bodies in support of organizing campaigns. In regulating wages and organizing the industry, they found common ground in increasing training and professionalism as well as in improving the pay and conditions of work..$^{8}$

Another SEIU partnership that succeeded was with the Australian Liquor Hospitality and Miscellaneous Union (LHMU) and the New Zealand Service and Food Workers Union (SFWU). Under the slogan "Clean Start: A Fair Deal for Cleaners", in 2006 these unions started a campaign to organize cleaners. 59 The SEIU sent organizers and research staff to Australia, some of whom had been involved in the Houston strike

56. Ibid., p. 62. On the London campaigns see also Jane Holgate, "Unionising the Low Paid in London: The Justice for Cleaners Campaign: A Case Study", unpublished paper, February 2009, available at: https://www.ilr.cornell.edu/sites/ilr.cornell.edu/files/Justice-for-Janitors-Case-Study.pdf; Wills, "Making Class Politics Possible", pp. 3I2-313; Fabienne Scandella, "Tel un phénix renaissant des poussières. Renouveau syndical dans le secteur du nettoyage. Analyse de la campagne londonienne 'Justice for cleaners'”, in Bouffartigue and Béroud, Quand le travail se précarise, pp. I I7-1 3 I.

57. Julie Hearn and Monica Bergos, "Latin American Cleaners Fight for Survival: Lessons for Migrant Activism", Race E Class, 53:I (201 I), pp. 65-82, 67 and 70.

58. Wills, "Making Class Politics Possible", pp. 3 I 5-3 I6.

59. Michael Crosby, "Clean Start - Fighting for a Fair Deal for Cleaners", in Gregor Gall (ed.), The Future of Union Organising: Building for Tomorrow (Basingstoke, 2009), pp. I 3 I-I 49. 
shortly before. ${ }^{60}$ Like everywhere else, the Australian and New Zealand cleaners were precarious workers from a predominantly non-English speaking immigrant background; sixty per cent were women. Some fifty organizers set up committees in the ten largest cities in Australia and New Zealand to mobilize the cleaners.

The campaign won wage increases of one-third and improvements in job security. ${ }^{6 \mathrm{I}}$ Again, regulating the industry was a primary goal of the campaign. The LHMU presented itself as working in the interests of the cleaning contractors and building owners: it was "aiming to achieve what the cleaning contractors have been unable to - a fair price. In the union's view, a fair price is one where building owners and managers engage cleaning firms on contracts that enable them to act as a responsible employer and enjoy some profit margin". ${ }^{62}$ One of the first to understand this logic was ISS, one of the biggest cleaning companies in Australia as well: "They identified very quickly that the crisis identified by the union was a crisis that undermined their ability to make money in the market. Tenders were continually undercut by contractors cutting labour costs". ${ }^{63}$

Also in 2006, the SEIU extended its Justice for Janitors campaign into Canada, at first in Toronto, later also in cities such as Ottawa and Vancouver, and at the University of Alberta (Edmonton). ${ }^{64}$ In Canada, the SEIU did not seek partnership with a cleaning union as it was the de facto cleaning union in the country (since the I940s; it justifies the "I" of "International" in the acronym SEIU). In 2006, the SEIU Toronto local began a campaign to organize cleaners, and, as of August 2009, more than 2,000 cleaners had been organized. Cooperation with other unions representing cleaners led to citywide agreements with four of the five largest companies in the Toronto market. ${ }^{65}$

\section{BECOMING VISIB LE}

Socially, the act of cleaning is invisible, despite the importance of the visibility of its results. Cleaning is often scheduled outside office hours so as not to coincide with normal activities. The spatial and temporal segregation of the workers, working conditions, and the unseen nature of the work tend to erase all traces of the presence of a cleaning workforce, unless, of course, the cleaning

60. Michael H. Crosby, Power at Work: Rebuilding the Australian Union Movement (Annandale, NJ, 2005), p. 5; McCallum, Global Unions, Local Power, p. 58.

61. McCallum, Global Unions, Local Power, pp. 58-6r; Cleaners and Community United for Justice [n.p., n.d.], available at: http://sfwu.org.nz/files/LOıos_CS_Com_Broc_Final_R\%20(2).pdf.

62. Aguiar and Ryan, "The Geographies of the Justice for Janitors", p. 955.

63. Crosby, "Clean Start", p. I 42.

64. For the Alberta case, see Jason Foster and Bob Barnetson, "Justice for Janitors in Alberta: The Impact of Temporary Foreign Workers on an Organizing Campaign”, Journal of Workplace Rights, I6:I (201 I-20I 2), pp. 3-29.

65. Aguiar and Ryan, "The Geographies of the Justice for Janitors", pp. 953-954. 
is not done, or perceived as poorly done. ${ }^{66}$ The issue of "visibility" became a recurrent theme in the cleaners' campaigns. Its resonance among the cleaners was an important element in the organizing drives everywhere. Interviewed about her motivation to become a shop steward in her workplace in Toronto, a Portuguese cleaner named Paula mentioned the invisibility of her work: "You know, the big bosses I heard got a bonus. But the cleaners, nobody stop and say thank you to you [...]. So, it's like they not see you. You are invisible”. The interviewers conclude "that the emotional cost of invisibility for workers, who feel unrecognized as cleaners, is partially mitigated for some through their visibility as active union members" ${ }^{67}$

Miami Justice for Janitors campaigner Feliciano Hernandez concluded in 2006: "We are no longer invisible. Before, our voice was a whisper. Now when we say we will stand up for our rights, our voice is loud and strong enough to be heard" ${ }^{68}$ Workers unionizing in Justice for Cleaners in London "felt invisible", like "ghost workers". ${ }^{69}$ For the Latin American cleaners involved in the University of London campaign in 2008, achieving "visibility" was at least as important as "bread and butter gains": "Now we are not invisible any more. Thanks to the campaign, people think differently about us". ${ }^{\circ}$ During the German strike in 2009, the slogan "Die Unsichtbaren sichtbar machen" ("Making the invisible visible") was added by Berlin strikers to the original union's slogan "Ich putze Deutschland", and after a while it was taken up throughout the sector. ${ }^{7 \mathrm{I}}$

From the start in 2006, the invisibility of the cleaners was a central issue in the Dutch campaigns too. The yell "Nooit meer onzichtbaar" (Never again invisible") dates from this early period, and was heard at every rally during the strikes in 2010 and 20I2, next to the slogan "Wat willen we? Respect! Wanneer willen we het? Nu!" "What do we want? Respect! When do we want it? Now!”). ${ }^{72}$ The cleaners argued that low wages and dismal working

66. Allen and Henry, "Ulrich Beck's Risk Society at Work", p. I89; Pai, "The Invisibles"; Fabienne Scandella, "Travail invisible dans un secteur de relégation. La double condition des nettoyeurs de bureaux", Les Mondes du Travail, 7 (2009), pp. 75 -86. Albert Recio and Alejandro Godino, "Invisible Workers: Quality of Employment in the Cleaning Sector in Spain”, Work and Life Quality in New\&Growing Jobs (WALQING) Social partnership series 20 I I. I 7, available at: http://www.walqing.eu/fileadmin/download/external_website/publications/WALQING_social partnershipseries_20II.I7_Cleaning_SP.pdf.

67. Urvashi Soni-Sinha and Charlotte A.B. Yates, “'Dirty Work'? Gender, Race and the Union in Industrial Cleaning”, Gender, Work \& Organization, $20: 6$ (20I3), pp. 737-75 I, 738 and 745.

68. Cited in Lerner et al., "Fighting and Winning in the Outsourced Economy", p. 255.

69. Wills, "Making Class Politics Possible", p. 317.

70. Interview with Eduardo (2008), cited in Hearn and Bergos, "Latin American Cleaners Fight for Survival”, p. 73.

71. German organizer Peter Riedel, cited by Fontana, A Comparative Analysis, pp. 57-58.

72. To be heard in YouTube video clips made of most of these rallies. The slogan was clearly copying those used in the US Justice for Janitors campaigns: "What do we want? Justice! When do we want it? Now!". 
conditions were closely related to their invisibility and to a lack of respect for their work. ${ }^{73}$ Judy Lock, a toilet cleaner at Schiphol Airport and one of the most prominent leaders in the Dutch 2010 campaign: "It is very strange that people walking by just don't see you. That you are invisible. Only when we came into the open with public protests did people become aware of our presence". ${ }^{74}$ And after the 20 I० strike, cleaner Bert Kuiper remarked: "What we achieved is respect as a human being, and appreciation for our work. [...] We are no longer invisible". ${ }^{75}$

\section{START OF THE DUTCH CAMPAIGN AT SCHIPHOL AIRPORT ${ }^{76}$}

Dutch cleaning presented all the characteristics of the industry described above. The market was saturated with thousands of small firms, but dominated by a small number of large companies. In $20 \mathrm{I}$, the largest was (unsurprisingly) ISS Cleaning Services. The five largest companies represented 49 per cent of the total workforce employed in the cleaning business (see Table I). The industry was highly diversified: 62 per cent of firms $(6,345)$ comprised self-employed without personnel (most of them were window cleaners); 29 per cent $(3,010)$ were very small, with 2-10 employees; 8 per cent (835) employed IO-Io० cleaners; and only I per cent (70) employed over 100. As everywhere, women were overrepresented in the workforce at 68 per cent; 46 per cent of the workforce were of nonDutch descent (both first- and second-generation migrants). The turnover of staff was very high: 35,000-40,000 new cleaners had to be recruited each year. Many cleaners had part-time jobs, which were often combined to earn a living: 27 per cent had contracts of less than I I hours; 30 per cent worked between $\mathrm{I} 2$ and 23 hours a week. ${ }^{77}$

The cleaning companies were engaged in a fierce competition. They had to cut prices to win contracts. Grasping the opportunities of the saturated market, and not being held back by any regulation, clients were inclined to

73. Lilian Marijnissen, "Met één hand kun je niet klappen. Over organising binnen de vakbeweging" (MA, University of Amsterdam, 2008), pp. 30-3 I, available at: http://www.scriptiesonline.uba.uva.nl/ document/I I 207I.

74. Interviewed in Heuts, Tegenmacht, p. 25.

75. "Nooit meer onzichtbaar", De Poetser. Ledenblad voor schoonmakers in Nederland (October 2010), p. 7 .

76. The cleaners' campaigns are documented in photos made at almost every occasion by Rob Nelissen (published online at http://mediabank.fnv.nl/) and in YouTube video clips. I consulted these as a source to find out about events during the campaigns and their exact dates (see appendix). Ron Meyer allowed me to use his collection of newspaper articles about the campaigns. These are referred to in the footnotes.

77. UWV, De Schoonmaak: Sectorbeschrijving (2013), pp. 9, I 8, available at: http://www.uwv.nl/ overuwv/Images/Sectorbeschrijving_schoonmaak_20I30716.pdf. 
Table I. The five largest cleaning companies in the Netherlands, 201 I.

\begin{tabular}{llrr}
\hline Company & Headquarters & Turnover & Workforce \\
\hline ISS Cleaning Services & De Meern & $€ 313,200,000$ & 15,200 \\
CSU Cleaning Services & Uden & $€ 268,000,000$ & 13,900 \\
Hago Nederland (Vebego) & Voerendaal & $€ 265,700,000$ & 10,135 \\
Gom schoonhouden (Facilicom) & Schiedam & $€ 212,800,000$ & 9,095 \\
Asito & Almelo & $€ 209,800,000$ & 9,566 \\
Total & & $€ 1,269,500,000$ & 57,896 \\
Cleaning branch & & $€ 3,560,000,000$ & 119,200 \\
\hline
\end{tabular}

Sources: "Marktoverzicht schoonmaakbranche 201 2", Service Management, 3 (March 20I3), available at: http://www.mbcf.nl/wp-content/uploads/20I 3/o2/Service-Management-markoverzicht-20I2.pdf; UWV, De Schoonmaak. Sectorbeschrijving.

pay less and less. In 20I 2, a report on the cleaning sector by the Dutch bank ABN AMRO signalled a fragmentation of the market because of the growth in the number of small firms, and the diminishing loyalty of clients, who easily switched contractors: "Cleaning companies have no market power. Existing contracts are regularly terminated in order to economize in terms of conditions and prices. Consequently, companies have to clean more square metres in substantially less time, and pressure on employees is rising" ${ }^{78}$ Often specialized mediators or brokers were used to find the most profitable contractor. Frequent change of contractor caused uncertainty for cleaners, and often also deteriorating working conditions. For the union, the only way out of this vicious circle was to build countervailing power in the labour market by organizing and mobilizing cleaners to put pressure on both clients and contractors.

Already in the I990s, the forerunner of FNV Bondgenoten, the Industriebond FNV, had concluded that existing collective agreements in the cleaning branch did not protect workers effectively. However, attempts to organize cleaners in a number of companies in 1992-1993 had met with disappointing results. ${ }^{79}$ In the early 2000 s, FNV Bondgenoten officials Mari Martens and Eddy Stam, responsible for the cleaning sector, learned about the Justice for Janitors campaigns through the film Bread and Roses by Ken Loach on Justice for Janitors in Los Angeles, and through their

78. ABN AMRO, Brancherapport schoonmaakbedrijven 20I2, available at: https://www. abnamro.nl/nl/images/Generiek/PDFs/020_Zakelijk/02_Sectoren/Zakelijke_dienstverlening/ zakelijkedienstverlening-branche-schoonmaakbedrijven.pdf.

79. Maarten van Klaveren and Wim Sprenger, "Union Organising in the Netherlands - A Combination of Organising and Servicing Strategies", in Gall, The Future of Union Organising, pp. 62-78, 71. See also Noor Goedhard and Kea Tijdens, Beroepsbinding en vakbondsoriëntatie in de schoonmaak. Een onderzoek in opdracht van de Industriebond FNV naar de vakbondsoriëntatie van werknemers in de schoonmaaksector (Amsterdam, 1993), available at: http://handle. net/I I $245 /$ I.35 I 546. 
contacts with the SEIU in Union Network International (UNI, now UNI Global Union), the global union federation for services. They managed to convince FNV Bondgenoten to cooperate with the SEIU. ${ }^{80}$ FNV policy adviser Dirk Kloosterboer wrote a report on the innovative organizing strategies of the SEIU and its Justice for Janitors campaigns. ${ }^{8 \mathrm{I}}$ Martens undertook a training course in organizing in the US and was charged with bringing back the approach to the Netherlands. He also participated in the Justice for Janitors campaign in Houston in $2006 .{ }^{82}$ On behalf of the SEIU, experienced activists, among them the Valery Alzaga cited at the start of this article, came to Amsterdam to coach Dutch union organizers. ${ }^{83}$ Four organizers were hired and trained to do the job in the Netherlands. Two of them were sent to London to participate in the Justice for Cleaners campaign there. ${ }^{84}$

In 2006, FNV Bondgenoten started an organizing campaign among cleaners in The Hague and at Schiphol Airport. ${ }^{85}$ Because of a lack of success in The Hague, in 2007 it was decided to discontinue the organizing efforts there and to concentrate organizing on Schiphol. ${ }^{86}$ This is reminiscent of the concentration on specific locations in Los Angeles (Century City) and London (Canary Wharf). Supported and coached by Valery Alzaga, organizers contacted Schiphol cleaners, making appointments at cafes or at home, ${ }^{87}$ and in that same year FNV Bondgenoten was able to bring thirty-three people together who wanted to become involved. They were from such diverse countries as Turkey, Morocco, Ghana, Bangladesh, the Antilles, Suriname, the Dominican Republic, Italy, and the Netherlands. ${ }^{88}$ Six of them were women, including Judy Lock, mentioned

80. Personal communication by Eddy Stam, is April 2016.

81. Dirk Kloosterboer, De vakbeweging van de toekomst. Lessen uit het buitenland (Amsterdam, 2005); a revised version was published in English in 2007: Innovative Trade Union Strategies, available at: http://www.scribd.com/doc/44286208/Innovative-Trade-Union-Strategies.

82. Personal communication by Mari Martens, 5 February 2016.

83. McCallum, Global Unions, Local Power, p. 64; Connolly et al., “'Justice for Janitors' Goes Dutch", pp. 8-9.

84. Ibid., p. 9. See also the television documentary "I Fight For You", first broadcast on I 8 September 2006, available at: http://www.npo.nl/tegenlicht-i-fight-for-you/21-07-2010/ WO_VPRO_043771.

85. De Poetser. Ledenblad voor schoonmakers in Nederland (July 2006).

86. Interview with Ron Meyer, lead organizer FNV Bondgenoten, 24 August 201 2, in Fontana, A Comparative Analysis, appendix, p. I06; see also https://www.fnv.nl/over-fnv/organisatie/ geschiedenis-van-de-fnv/geschiedenis-fnv-2005-heden/.

87. For an account of the activities of FNV Bondgenoten organizer Herrie Hoogenboom at Schiphol, see De fabel van de illegaal, 84 (May/June 2007), available at: http://www.doorbraak. eu/gebladerte/I I $329 f 84 \cdot h t m$. For the involvement of Valery Alzaga, see the interview with Ron Meyer in Fontana, A Comparative Analysis, p. ı08; https://www.globalinfo.nl/Nieuws/steun-deschoonmakers, I2 October 2007, and Rob Lubbersen, "Schoonmakers winnen!", Grenzeloos, I9 February 2008, available at: http://www.grenzeloos.org/content/schoonmakers-winnen.

88. Eddy Stam, “Kadergroep Schiphol”, De Poetser. Ledenblad voor schoonmakers in Nederland (October 2007). 
above: "An FNV organizer approached me while I was drinking coffee and discussing work with a colleague after work", she later recalled. ${ }^{89}$ She became president of the Cleaners' Committee at Schiphol and a prominent spokeswoman for the cleaners during the 2010 strike. On 17 November 2007, a preliminary meeting of 500 cleaners was held in the Holiday Inn Hotel at Schiphol to launch a campaign for higher wages (at $€_{\mathrm{I} O}$ an hour) under the slogan "Voor een betere toekomst" ("For a better future").9" Demonstrations at Schiphol and at offices of clients elsewhere in the Netherlands, and other symbolic actions, such as visits to the private mansions of directors of cleaning companies (a "millionaires' tour"), put pressure on negotiations with employers. ${ }^{91}$ In January 2008, a new nationwide contract was signed, which included a pay rise from $€ 8.90$ to $€_{\mathrm{I}} \mathrm{O}$ an hour. ${ }^{92}$ Unlike, for instance, in the US, collective agreements in the Netherlands are negotiated nationally, and then made legally binding for the branch as a whole.

A conference of sixty-five activists at the beach resort of Renesse on 2 I and 22 April 2008 decided to start a new campaign at Schiphol with the slogan "Schiphol Schoon Genoeg" ("Schiphol Clean Enough"), demanding travel allowances for Schiphol cleaners, better facilities at the airport, and a fixed contract after nine months' working. The campaign started in November 2008 with a week of picketing and a march around the airport. Some 250 activists were recruited, and, after several demonstrations and a four-day strike involving 500 cleaners (half of the workforce) at Schiphol, in the first week of April 2009 they won travel allowances, a $€_{\mathrm{I}}$ 0 bonus for the Schiphol cleaners, and a 0.5 per cent wage increase for all cleaners nationwide. ${ }^{93}$ There were smaller pickets by cleaners elsewhere in the country as well, but concentrating the campaign on Schiphol made it clear how much could be achieved by a relatively small number of dedicated activists. Union organizer Ron Meyer recalled in 201 2: "From 2008/2009 we started at Schiphol and in 2009 we had a strike for a couple of days

89. Emma Boelhouwer, "Staking heeft schoonmakers ogen geopend", Het Parool, I4 April $20 \mathrm{I}$. 90. De fabel van de illegaal, 89/90 (Winter 2008), available at: http://www.doorbraak.eu/gebladerte/ I I 384 f89.htm. Koen Haegens, "Het nieuwe werken op Schiphol: opstand der schoonmakers", De Groene Amsterdammer, I6 November 2007.

91. Marijnissen, "Met één hand kun je niet klappen", pp. 6-7, 28-32.

92. FNV Bondgenoten, Mensen Voorop. Jaarverslag 2008 (Amsterdam, 2009), p. 6; Nico Lemmens, "Deregulering in de schoonmaak. Over de nieuwe schoonmaak-CAO", Facility Management Informatie (May 2008), pp. 54-57.

93. http://www.facility.vakwereld.nl/Nieuws/I/2365: "FNV Bondgenoten voor rechter gesleept"; I/2394: "Schoonmakers op Schiphol staken"; I/242 I: "Schoonmakers Schiphol blijven in staking"; FNV Bondgenoten, Mensen Voorop. Jaarverslag 2008, p. 33; De Poetser. Ledenblad voor schoonmakers in Nederland (March 2009): "Beeldverslag van de acties Schiphol"; "Schiphol, de feiten"; ibid. (September 2009): "Schoonmakers voeren actie voor een goede cao. Een fotoreportage"; Rob Rombouts, “Schoonmakers aan de slag na akkoord”, Het Parool, 8 April 2009. 
with some 200 cleaners. And that was a real start of learning and getting an idea about how to plan and how to talk to people and how to organize". ${ }^{94}$

\section{THE 2010 AND 2012 NATIONAL STRIKES}

To evaluate the Schiphol campaign and to prepare the negotiations for a renewal of the national collective agreement in 2010, another two-day conference was held on 25 and 26 May 2009, again in Renesse, with fifty representatives from various parts of the country. The conference decided to rename itself "Cleaners' Parliament", and to demand additional travel allowances, no more waiting days in the event of illness, Dutch lessons for migrants in working time, and a three per cent wage rise. ${ }^{95}$ For the cleaners at the conference, the most important issue was respect for the cleaner and cleaning as a profession. This was lost, in their opinion, because clients and cleaning companies were competing only over its price. Wages were under pressure, and cleaners were forced to work harder and harder at the expense of the quality of their work. ${ }^{96}$

At a meeting of this "parliament", now enlarged to comprise seventy-five members, held on I 2 December 2009 at Amsterdam's town hall, a white paper on the cleaning industry in the Netherlands was presented to substantiate this argument. ${ }^{97}$ The sector is in crisis, the report argued. While cleaning as an industry is growing fast, contracting out and the competition between cleaning companies cause uncertainty, instability, and downward pressure on prices in a race to the bottom. Consequently, wages, working conditions, and cleaning standards are undermined. It is in the interests of the sector as a whole - clients, cleaning companies. and cleaners - to put an end to this crisis by regulating standards of work and working conditions. Clients especially are vulnerable to being confronted with low-quality work, because "the cleaning companies have degraded themselves to become clubs of cheap labour, and they are prepared to sink even lower"..$^{8}$

In negotiations with the representatives of the cleaners' union, the cleaning companies showed no inclination whatsoever to concede to any of

94. Interview with Ron Meyer, in Fontana, A Comparative Analysis, appendix, p. I07; http:// www.facility.vakwereld.nl/Nieuws/I/2394: "Schoonmakers op Schiphol staken", mentions 500 strikers.

95. De Poetser. Ledenblad voor schoonmakers in Nederland (September 2009), pp. 7-8.

96. Ibid. (May 2010), p. 7. For the cleaners demanding "respect", see the interview with Ron Meyer in Fontana, A Comparative Analysis, appendix, p. I I 2.

97. De Poetser. Ledenblad voor schoonmakers in Nederland (January 2010), pp. 5-7.

98. Schoon genoeg. Op naar een betere toekomst voor de schoonmaaksector! (Amsterdam, 2009), p. I4. 


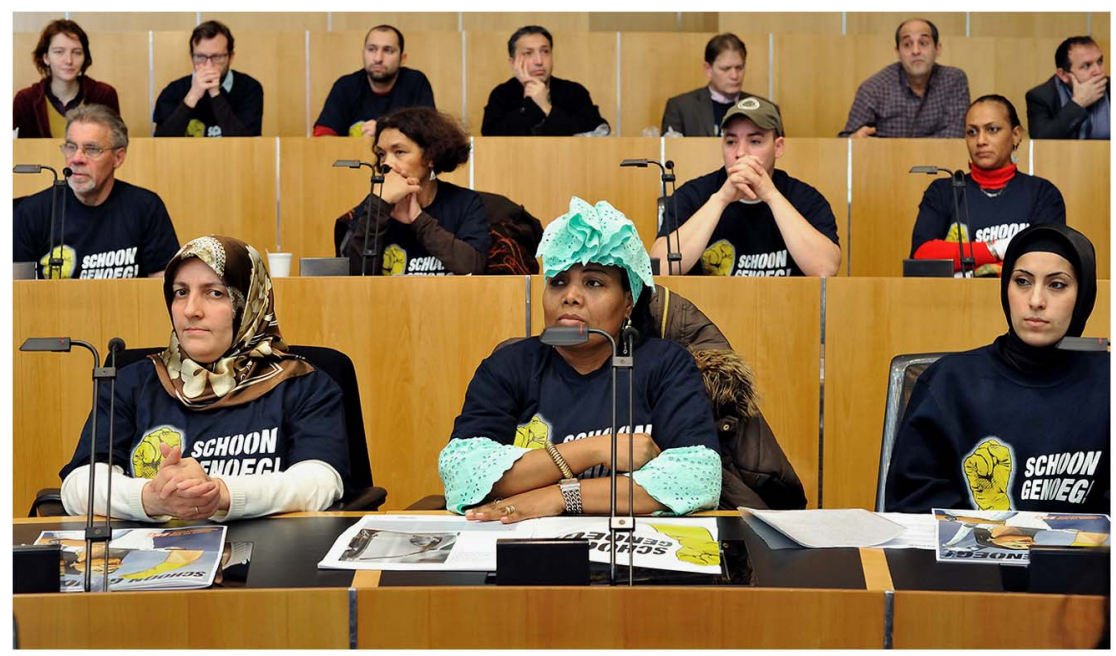

Figure 3. Meeting of the "cleaners' parliament" in the Amsterdam town hall, I2 December 2009. Photograph by Rob Nelisse. Used with permission.

the demands formulated by the union. ${ }^{99}$ The "Cleaners' Parliament" therefore decided to call a strike in 2010. After a month of short warning strikes, pickets, meetings, and demonstrations at different locations, the strike was officially called on I 6 February. The total number of strikers was around I,400, ${ }^{100}$ surprisingly low compared with the I 5,000 union members in the cleaning sector. However, because of the high participation of train cleaners (400 strikers), its consequences were notable at railway stations and in trains, and the relatively small number of strikers was compensated by almost daily actions and protests, clearly copied from the US Justice for Janitors "militant minority" repertoire (see appendix). These actions were consciously designed to put pressure on clients of the cleaning companies by getting as much media attention and public support as possible - by showing colourful banners, handing over symbolic presents, sewing "the largest cleaning cloth in the world", banging drums, having all demonstrators wear orange FNV jackets, and the like. The campaign found a strong resonance with the Dutch population: signatures and testimonials were widely collected, and public figures and celebrities pledged their

99. Elsbeth Stoker, "Gesprekken over cao schoonmaak vastgelopen", de Volkskrant, 9 December 2009.

Iо०. Heuts, Tegenmacht, p. I 2; elsewhere the number of strikers is estimated to have been even lower: Heuts, “No More Being Ground Down For Us"” ( 1,000$)$; "Schoonmakers hervatten werk na cao-akkoord”, NRC Handelsblad, 22 February 2010 (1,100). 
support. On 2I April, the international union UNI Global Union announced the start of a solidarity campaign of picketing at Dutch embassies, ${ }^{\text {IOI }}$ but this proved unnecessary as an agreement was reached on 22 April.

As was intended, the perseverance of the strikers put pressure on the clients of the cleaning companies, foremost Schiphol and the NS railway company. They demanded arbitration to put an end to the strike. In the press, representatives of the cleaning companies now endorsed the analysis of the union's "white paper" that the sector was "in crisis", admitting that the market had been ruined by competition and a race to the bottom. ${ }^{\text {I02 }} \mathrm{On}$ 22 April an agreement was reached on a 3.5 per cent pay rise over the next two years, a bonus of I 8 per cent for the strikers, and opportunities to learn Dutch in working time. Both clients and contractors agreed to cooperate in a covenant for good employment practices, or "code for responsible market behaviour in the cleaning industry". ${ }^{103}$

Employers' representatives now welcomed the new agreement because "without a contract, cleaning companies would compete even more on lower prices and wages. That would be to the detriment not only of the cleaners, but also of the small and medium-sized cleaning companies". ${ }^{104}$ Representatives of the large cleaning companies CSU and HAGO admitted that the strike had opened their eyes to the detrimental effects of competition. ${ }^{\text {IOS }}$ The former human resources manager at NS, now chair of the committee to supervise the above "code", even stated: "in hindsight, some employers recognize that the strike revealed the stranglehold they were in". As the Dutch law on free competition forbade the regulation of markets by minimum tariffs, a voluntary code on market behaviour was deemed necessary to prevent a downward spiral in tendering. ${ }^{106}$ Clearly, for these employers, the collective agreement and the "code of conduct", enforced by the strike action of the cleaners, were instruments to regulate the market. It is a sign that "regulatory unionism", as practised in Los Angeles, London,

Iог. Elsbeth Stoker, "Internationale steun schoonmakers”, de Volkskrant, 21 April 2010.

I02. Jurry Brand and Jarco de Swart, "Opdrachtgevers pakken rol op in schoonmaakconflict", De Telegraaf, 5 March 2010; Elsbeth Stoker, "Schoonmakers pikken het niet langer", de Volkskrant, s March 2010; idem, "Wie betaalt inburgering schoonmakers?", de Volkskrant, I 8 March 20I0; "Topman Schiphol springt op de bres voor schoonmakers", Trouw, 9 April 2010. I03. "Schoonmakers hervatten werk na cao-akkoord"; "Positie van schoonmakers verbetert", NRC Handelsblad, 22 April 2010. The code was signed on 2 I June 201 i: De Poetser. Ledenblad voor schoonmakers in Nederland (October 20II), p. 5. See also http://www.codeverantwoordelijkmarktgedrag.nl/home/.

I04. Cited by Sander Heijne and Elsbeth Stoker, "Cemal wil niet twee jaar wachten op die 3,5 procent", de Volkskrant, 23 April 2010.

I05. Heuts, Tegenmacht, pp. 16, 89; they repeated this opinion in the television programme Zembla, "Schoonmaakwoede", 23 May 2010.

ıо6. Heuts, Tegenmacht, pp. I I I-I I 2. 
and Australia, was an important element in the cleaners' struggle in the Netherlands as well.

"Regulatory unionism" can be effective, however, only if a union is able to exert enough power in the labour market. On 24 and 25 October $20 \mathrm{II}$, a newly elected "Cleaners' Parliament" assembled at the trade union centre Burcht van Berlage, the former headquarters (built in 1900) of the iconic Dutch diamond workers' union in Amsterdam. Pictures of this meeting reveal the colourful and multicultural character of its membership and the prominent role of women among the activists. The "parliament" chose a twelve-member strong "cabinet" and the Amsterdam hospital cleaner Khadija Tahiri as its president. The "parliament" discussed demands for the renewal of the collective agreement in 20I 2: a lower workload, a wage rise of $€_{0} .50$ an hour, an annual bonus of $€_{300}$, and - a demand remaining from the previous round of negotiations - no waiting days in the event of illness. The voluntary "code of conduct" was deemed a fig leaf, because it was used only as an instrument to regulate the tendering of the cleaning companies, not to protect cleaners. Competition on prices was replaced by competition on working conditions and increasing workloads. ${ }^{107}$ This argument was supported in a new "white paper", discussed at another meeting of the "Cleaners' Parliament" in Rotterdam on is December 20I I. ${ }^{\text {I08 }}$ FNV Bondgenoten proposed to introduce sharper regulation of the market, in what it called a "Gold Standard", but it could not convince the cleaning companies. ${ }^{109}$ Instead, they reproached the union for not complying with the "code", which apparently for them was primarily an instrument to pacify industrial relations. ${ }^{\text {IO }}$

Negotiations on the unions' demands were broken off by the cleaning employers on 8 December 20II. On 2 January 20I2, the next strike was called. The tactics and repertoires were very much like those in $20 \mathrm{IO}$, but on a larger scale. There were now 3,000 strikers in total and the strike targeted more locations. Throughout January and February there were ten large "marches for respect" in different localities around the country, each with several thousand participants. Countless events, pickets, and meetings were

I07. Henk Cornelisse, "FNV Bondgenoten als huwelijkskandidaat”, Clean Totaal, 4 November 20II; Marike Stellinga, "Schoonmaakparlement 'geeft nooit toe", NRC Handelsblad, 25 November 201 I. An overview in 2013 showed that only nine out of nineteen big clients had signed the "code": FNV Schoonmaak, Gewoon schoon! De schoonmaaksector anno 2013 (Amsterdam, 2013).

I08. FNV Bondgenoten/Vakbond van schoonmakers, Let's get real. Schoon genoeg van de schijnwereld in de schoonmaaksector (Amsterdam, 20I I).

ıо9. Ibid.; Henk Cornelisse, "FNV Gouden Standaard: Alles goud wat er blinkt?", Clean Totaal, 9 December 20 I I.

I Iо. Henk Cornelisse, "FNV Bondgenoten: Schoonmaakstaking als reddingsboei?", Clean Totaal, 4 January $20 \mathrm{I} 2$. 


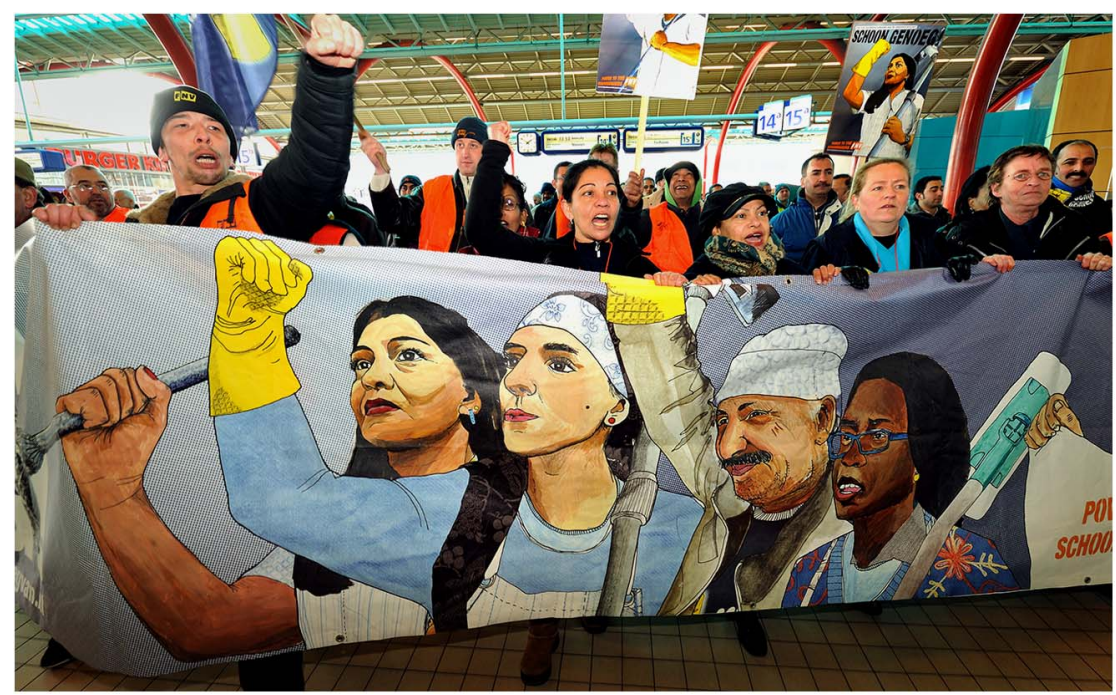

Figure 4. March by some 400 cleaners during a sit-in at Utrecht Central Station, I6 March 2010. Photograph by Rob Nelisse. Used with permission.

held; public support was mobilized; some 6,000 emails offering support were received from all over the world. ${ }^{\text {I I }}$

In April, a few individual cleaning companies and three of the hardest hit clients, railway company NS, Schiphol Airport, and the Rotterdam Erasmus Medical Centre, urged the employers to reach a compromise with the union. On I 6 April, after a strike lasting ios days, the cleaning companies finally realized that regulating the market would be possible only at a higher level of wages and with improved working conditions. Parties agreed on a pay rise of 4.85 per cent over two years, better training facilities, and more fixed contracts for agency workers. On payment during the first few days of illness, a compromise was reached, with the parties agreeing to investigate this issue further. The cleaners had to wait for the next round of negotiations and a twelve-week strike in 20I 4 to finally achieve this goal; it was secured despite, again, the relatively low number of strikers $(\mathrm{I}, 400) .{ }^{\mathrm{II} 2}$ In the meantime, they continued their meetings and discussions in the "Cleaners' Parliament" and remained confident about the power of organizing.

It is not yet clear what the future of the Dutch cleaners' union will be, but to others in and outside the union they set an example of how to combat the detrimental effects of neoliberal restructuring and the precariatization of

I I I. For an overview, see http://www.schoongenoeg.nu, and the leaflet in Schoon genoeg! Respect voor schoonmakers, I (May 20I2).

I I2. For an overview, see Schoon genoeg! Respect voor schoonmakers, 6 (July 20I4). 
work. One of the more spectacular actions during the 2012 strike was the occupation of the VU University Amsterdam on 5 March by I,000 cleaners. ${ }^{113}$ The occupation coincided with protests by students and staff against university reforms and cuts, and the university committee called on them to show solidarity with the cleaners. According to the then student leader and Ph.D. student Matthias van Rossum, it was a turning point in the university campaign:

Although the kind of work differs a lot, the problems of university staff and cleaners are in fact very much alike: flexibilization, undermining of work standards and diminishing influence on labour relations, lack of appreciation, hardening of management styles. The cleaners' occupation made a huge impression on the university staff. They became aware that if the cleaners can organize, they should be able to do so too. ${ }^{\mathrm{II} 4}$

\section{CONCLUSION: REGAINING CHARACTER}

In his well-known book The Corrosion of Character, on the psychological effects of the fragmentation and flexibilization of labour markets in modern capitalism, Richard Sennett refers to a janitor he interviewed for his earlier work The Hidden Injuries of Class (1972):

Enrico had spent twenty years by the time we first met cleaning toilets and mopping floors in a downtown office building. [...] His work [...] seldom varied from day to day. And along that time, achievement was cumulative: Enrico and [his wife] Flavia checked the increase of their savings day by day [...] the time they lived was predictable $[\ldots]$ unions protected their jobs; though he was only forty when I first met him, Enrico knew precisely when he would retire and how much money he would have. ${ }^{\text {II }}$

Today, such a well-organized and future-oriented life plan for cleaners is difficult to imagine. ${ }^{\mathrm{II}}$ Since Sennett wrote this book in 1972, employers have increasingly distanced themselves from workers through the use of subcontracting, labour-market intermediaries and agencies, and selfemployed contractors. This restructuring caused a break with the postwar

I I3. "Schoonmakers, VU-personeel en studenten: de kracht van gezamenlijke strijd", 3 April 20r2, available at: http://socialisme.nu/blog/nieuws/25406/schoonmakers- $\%$ e2 $\% 80 \% 98$ het-besef-hoekrachtig-gezamenlijke-strijd-kan-zijn\%e2\% $80 \% 99 / \#$ sthash.poHpueqD.dpuf.

I I 4. Matthias van Rossum, "Werken van onderop, maar ook van bovenaf de vakbond veranderen", Grenzeloos, I9 May 2015, available at: https:/www.grenzeloos.org/content/werken-van-onderopmaar-ook-van-bovenaf-de-vakbond-veranderen. Van Rossum is now a senior researcher at the International Institute of Social History in Amsterdam.

I I s. Richard Sennett, The Corrosion of Character: The Personal Consequences of Work in the New Capitalism (New York and London, 1998), pp. I 5-16.

I I6. Pension rights of flex workers, such as cleaners, are often fragmented because of short-term and part-time contracts, and low wages: "Flexwerkers moeten later een écht pensioen krijgen", NRC Handelsblad, 16 April 2016. 
"standard employment relation" for male workers like Enrico. The negative impact on wages and welfare provisions is particularly visible in the cleaning business. Cleaners all over the world increasingly work for companies that compete for often short-term contracts with clients. As they are no longer employed by the client firm, employers are able to shed responsibility for the maintenance of labour standards, social security, and other rights.

The outsourcing of cleaning allowed for the recruitment of people outside regulated labour markets. Everywhere, immigrants are overrepresented in the cleaning workforce, which in addition comprises many women with part-time, irregular jobs. Especially in large "global cities", labour markets are polarized, with mobile workers both at the top and bottom segments. ${ }^{117}$ Low-paid workers, in building maintenance for example, are indispensable if the city (and its top layers) are to work. Most of the workers at the lower end are migrants. They, more than anyone else, experience the psychological effects of the flexibilization of labour markets, described by Sennett as "the corrosion of character":

The system $[\ldots]$ radiates indifference $[\ldots]$ through reengineering of institutions in which people are treated as disposable. Such practices obviously and brutally diminish the sense of mattering as a person, of being necessary to others. [...] Under these conditions, character corrodes: the question "Who needs me?" has no immediate answer. ${ }^{\text {I } 8}$

In such a fragmented and highly individualized labour market, social cohesion and common ground to organize collectively are hard to find. The prospect of unionizing by precarious, immigrant workers is not immediately self-evident; efforts to do so have often led to disappointing results. Unions considered workers such as cleaners hard to organize, also because they work out of sight, alone, or in small groups, so that organizing at the workplace did not really seem feasible.

This changed when unions like the SEIU in the US and FNV Bondgenoten in the Netherlands put financial and personal resources into organizing campaigns and sent in specially trained organizers. By offering opportunities for cleaners to become active themselves, by identifying and training rank-and-file leaders, and by inventing a whole range of new repertoires of direct action, they were able to turn the social and psychological disadvantages of isolation, invisibility, and precariousness into a moral advantage. The cleaners' campaigns principally aimed to make the invisible and largely immigrant workforce highly visible in the public sphere by undertaking strikes, demonstrations, and "shaming rituals" in or near the glittering skyscrapers in the financial districts, transport hubs, and 
other crucial sites of the wealthy, such as the mansions of managermillionaires. Smaller and larger manifestations, demonstrations, occupations, picket lines, festive parties, and gatherings, with colourful banners and vests, gestures, songs, and yelled slogans, all had the effect of empowering and enthusing the participants collectively. ${ }^{\text {II } 9}$ Framed as a morally compelling cry for social justice, respect, and recognition, the cleaners' campaigns won the sympathies of the public as well as key members in political and media arenas.

Some labour movement activists and writers in the US have criticized the SEIU's Justice for Janitors campaigns as too much top down, rather than being initiated and sustained from below by the rank and file. In some instances, these critics say, the SEIU has practised old-style union authoritarianism, thereby failing to really involve and empower workers. ${ }^{120}$ However, confidence in a "rank-and-file strategy" without institutional backing by established unions is hard to gain in a situation of fragmentation and isolation of precarious workers, such as cleaners. Once offered opportunities to organize and fight back by the top-down efforts of union organizers, a core of conscious cleaners, especially women, were able to regain their "sense of mattering as a person" and their dignity as a worker, to develop leadership, and to put energy into campaigning for their rights collectively. This energy would not have been mobilized without organizing top down by the established unions, while top-down organizing would have been useless without mobilizing this energy from below.

While based on inventive new repertoires of public action to overcome the degradation, isolation, and invisibility of the mostly immigrant and female workforce in outsourced cleaning, the strategies of the cleaners' unions in the US, London, Australia / New Zealand, and the Netherlands were all geared towards what can be defined as the core business of trade unionism: regulating labour markets by agreeing with employers and clients to "take wages out of competition". As Ruth Milkman emphasized in her study on the Los Angeles case, there is a long history of this type of regulatory unionism, both in the US and in Europe. ${ }^{\text {II }}$

I 19. For a comprehensive analysis of the empowering effects of the action repertoires, see Dylan Paauwe, "Tegenkracht. Een onderzoek naar de kwalitatieve aspecten van het organising-model in de schoonmakersstaking van 20I2" (BA, University of Amsterdam, 20I2), available at: http:// dare.uva.nl/cgi/arno/show.cgi? fid $=459794$.

I 20. The most pertinent of these critics, not so much of the Justice for Janitors campaign itself as of the SEIU's internal organization, is Kim Moody, US Labor in Trouble and Transition: The Failure of Reform from Above, The Promise of Revival from Below (New York, 2007). See also McCallum, Global Unions, Local Power, pp. 67-69.

I 2I. Nineteenth- and early-twentieth century examples can be found in Ad Knotter, "Trade Unions and Workplace Organization: Regulating Labour Markets in the Belgian and American Flat Glass Industry and in the Amsterdam Diamond Industry in the Nineteenth and Early Twentieth Centuries”, Labor History, 57:3 (2016), pp. 41 5-438. 
From this perspective, the organizing campaigns invented by Justice for Janitors were innovative in form, ${ }^{\mathrm{I} 22}$ but quite traditional in content. The regulatory unionism as practised in the campaigns presupposed a spatial labour market that could be territorially defined and regulated. In the US and Great Britain, where contracts had to be negotiated locally firm by firm, the campaigns had a "zonal" approach and were aimed at unionizing cleaning firms locally and zone by zone. In the Netherlands, this was tried with some success at Schiphol Airport, where, in 2008, separate benefits were obtained for the cleaners working there, but, as a consequence of the Dutch system of industrial relations, the Dutch campaigns could gain strength only by organizing nationwide to enforce national collective agreements.

From this regulatory perspective, the endeavours of the SEIU to focus transnational campaigns on multinational cleaning companies such as ISS and to negotiate transnational or "global" contracts were somewhat paradoxical, as union power to enforce labour market regulation still had to be developed locally, or, as in the Dutch case, nationally. The SEIU's Stephen Lerner's maxim that "the building owners are global, the investment capital is global, the contractors are global, and the workers are global" may be true, ${ }^{\mathrm{I} 23}$ but not enough to warrant a globally organized labour market. For me, it remains completely unclear how, as Lerner asserts, "through global agreements episodic campaigning may move toward a much-needed institutionalized power capable of challenging global capitalism systematically". ${ }^{24}$ The migrant labour force may be as transnational as the multinational cleaning companies, the labour markets on which both parties operate are still institutionalized locally or nationally. The transnationalism of the SEIU and its international partners in UNI Global Union concerns officials and organizers, not the cleaners themselves. It can connect the local and the global only by supporting efforts to build union capacity at a local or national level, while simultaneously organizing global support for cleaners campaigning for their rights. In spite of the general framework provided by the Socially Responsible Contractor Global Agreement signed by UNI Global Union and ISS, the global appeal of Justice for Janitors was, and still is, based on international solidarity, not on transnational labour market regulation.

\footnotetext{
I22. I do not engage here in the debate as to whether the Justice for Janitors' repertoire was an original "invention" or a "revival" of older union tactics. As stressed by Charles Tilly, most contemporary forms of contention adapt, permute, and innovate repertoires inherited from the past.

I 23. Lerner, “Global Unions”, p. 29.

I 24. Cited in David Moberg, "Translating Solidarity: As SEIU Organizes on a Global Scale, It Must Adapt Its Approach to Accommodate Cultural Differences”, The American Prospect, 2I:10 (2010), Ai 2.
} 
A symbol of this kind of international solidarity was presented by UNI Global Union when it awarded the Dutch "Schoon genoeg!" campaign of 2010 the prize for the world's best trade union campaign in the last five years. Cleaners' representatives Judy Lock and Christine Monk, together with FNV Bondgenoten official Mari Martens, went to Tokyo to receive the honour. For Christine Monk, the international prize "meant a great deal of support not only for us cleaners, but also for our colleagues in, for instance, security, catering, home care, and nursing. Its message is: you can win if you want to!"125

\section{TRANSLATED ABSTRACTS \\ FRENCH - GERMAN - SPANISH}

Ad Knotter. Justice for Janitors aux Pays-Bas. Le travail précaire et la réponse syndicale dans l'industrie du nettoyage (1988-2012). Une histoire transnationale.

Le travail précaire a augmenté depuis les années 1970 et 1980 dans le monde entier. Les relations de travail changeantes dans l'industrie du nettoyage témoignent de ces évolutions. À partir des années 1970, l'externalisation transforma fondamentalement la position des nettoyeurs industriels: les entreprises de sous-traitance purent réduire les coûts de la main-d'œuvre en recrutant principalement des femmes et des immigrants à la position faible sur le marché du travail. Les syndicats eurent des difficultés à trouver le moyen de contrer cette tendance et à organiser ces travailleurs, jusqu'à ce que les campagnes Justice for Janitors $\left(J_{4} J\right)$, créées par le Service Employees International Union (SEIU) aux É.-U. à partir de la fin des années 1980 montrèrent qu'une réponse syndicale appropriée était possible. À partir du milieu des années 2000, le SEIU lança une stratégie pour former des coalitions internationales en dehors des É.-U. Elle rencontra un écho favorable dans plusieurs pays. Aux Pays-Bas, une campagne sur le modèle $\mathrm{J}_{4} \mathrm{~J}$ remporta un succès extraordinaire. Dans cet article, le syndicalisme transnational, fondé sur le modèle $\mathrm{J}_{4} \mathrm{~J}$, dans l'industrie du nettoyage sera analysé en se concentrant particulièrement sur le cas néerlandais. Comment les marchés du travail locaux et les actions syndicales se sont rattachés aux liens transnationaux apparents dans l'essor des sociétés de nettoyage multinationales, la main d'œuvre immigrante et le rôle du SEIU pour promouvoir la coopération internationale entre les syndicats?

Traduction: Christine Plard

Ad Knotter, Justice for Janitors auf Holländisch. Prekäre Arbeit und die Antwort der Gewerkschaften im Reinigungsgewerbe (1988-2012). Eine transnationale Geschichte.

Prekäre Arbeit breitet sich seit den I970er und I980er Jahren im globalen Maßstab aus. Die im Wandel begriffenen Arbeitsverhältnisse im Reinigungsgewerbe sind ein Beispiel für diese Entwicklung. Seit den I970er Jahren hat das outsourcing die

I 25. Cited in "Hollandse schoonmakers zijn wel wereldkampioen", De Telegraaf, 9 November 2010. 
Stellung der Reinigungskräfte grundlegend verändert: Subunternehmen waren in der Lage, die Lohnkosten zu senken, indem sie vor allem Frauen und Einwanderer rekrutierten, deren Verhandlungsposition auf dem Arbeitsmarkt schwach ist. Den Gewerkschaften ist es schwer gefallen Mittel zu finden um dieser Tendenz entgegenzuwirken und die Arbeiter zu organisieren, bis die von der US-amerikanischen Service Employees International Union (SEIU) seit Ende der I980er Jahre organisierten Justice-for-Janitors- oder J4J-Kampagnen zeigten, dass eine wirksame Antwort seitens der Gewerkschaften möglich ist. Ab Mitte der 2000er Jahre verfolgte die SEIU die Strategie, internationale Koalitionen außerhalb der USA aufzubauen. Dieser Ansatz wurde in mehreren Ländern wohlwollend aufgenommen. In den Niederlanden erwies sich eine auf dem J4J-Repertoire begründete Kampagne als überaus erfolgreich. Der Beitrag untersucht die auf dem J4J-Modell beruhende transnationale Gewerkschaftsarbeit im Reinigungsgewerbe und fokussiert dabei insbesondere auf die Niederlande. In welchem Verhältnis standen lokale Arbeitsmärkte und das gewerkschaftliche Vorgehen zu den transnationalen Verbindungen, die sich im Aufstieg multinationaler Reinigungsfirmen, im Einsatz migrantischer Arbeitskraft sowie in der Rolle der SEIU bei der Förderung internationaler gewerkschaftlicher Kooperation zu erkennen geben?

Übersetzung: Max Henninger

Ad Knotter. 'Justice for Janitors' se marcha a Holanda. Trabajo precario y respuesta sindical en el sector de la limpieza (1988-2002). Una historia transnacional.

De forma global, el trabajo precario ha ido en aumento desde las décadas de I 970 y 1980. Los cambios en las relaciones laborales en el sector de la limpieza son un ejemplo de esta tendencia que señalamos. Desde los años 70 en adelante, el proceso de externalización modificó profundamente la situación de los limpiadores: a través de las empresas de subcontratas se tenía la posibilidad de reducir costes laborales contratando principalmente mujeres e inmigrantes con un débil posición en el mercado de trabajo. Para las organizaciones sindicales era complicado tanto encontrar una forma de actuar frente a esta tendencia como organizar a estos trabajadores hasta que las campañas Justice for Janitors -J4J-, organizadas por la sede estadounidense del Sindicato Internacional de Trabajadores de Servicios (SEIU) a finales de la década de I980, pusieron de manifiesto que era posible plantear una acción sindical adecuada. A mediados de los años 2000, el SEIU promovió una estrategia destinada a establecer coaliciones internacionales fuera de los Estados Unidos. Esta iniciativa encontró una respuesta favorable en diferentes países. En los Países Bajos se demostró extraordinariamente efectiva una campaña diseñada en el repertorio desarrollado por $\mathrm{J}_{4} \mathrm{~J}$. En este artículo el asociacionismo sindical transnacional en el sector de la limpieza basado en el modelo $J_{4} J$ será analizado prestando una atención especial al caso holandés. ¿Cómo eran los mercados de trabajo locales y las acciones sindicales relacionadas con las conexiones transnacionales que surgieron en el crecimiento de las empresas de limpieza multinacionales? ¿Cómo era la fuerza laboral inmigrante? ¿Cuál fue el papel del SEIU en la promoción de la cooperación internacional entre sindicatos? 


\begin{tabular}{|c|c|c|c|c|}
\hline Date & Place & Type of action & $\begin{array}{l}\text { Estimated no. of } \\
\text { participants }\end{array}$ & Details \\
\hline 04-01 & Eindhoven & Visit to boss of cleaning company & 20 & Warning strike \\
\hline 09-01 & Venlo & Brief strike among train cleaners & 20 & \\
\hline $13-01$ & 's-Hertogenbosch & $\begin{array}{l}\text { Visit to a conference of employers in the cleaning } \\
\text { branch }\end{array}$ & 50 & $\begin{array}{l}\text { Employers receive a "golden pilferer" (the Dutch } \\
\text { terms means both a thief as well as a small vacuum } \\
\text { cleaner) }\end{array}$ \\
\hline 14-01 & Schiphol Plaza & Protest & 50 & $\begin{array}{l}\text { Cleaners show that they are prepared to strike to } \\
\text { enforce their demands }\end{array}$ \\
\hline $15-01$ & Rotterdam & Visit to directors of academic hospital & 25 & \\
\hline $20-01$ & The Hague & Meeting at Plein Square & 50 & Also against higher retirement age \\
\hline $30-01$ & Amsterdam & March from Central Station to Dam Square & 100 & $\begin{array}{l}\text { Dusters are sewn together to form the "largest duster } \\
\text { in the world" }\end{array}$ \\
\hline 01-02 & Rotterdam & Visit to World Trade Center & 20 & Ditto \\
\hline $02-02$ & Rotterdam & Visit to financial institutions and academic hospital & 20 & Ditto \\
\hline $04-02$ & Utrecht & Visit to railway maintenance company Nedtrain & 25 & Ditto \\
\hline $06-02$ & Groningen & Central Station & 25 & $\begin{array}{l}\text { Groningen railway cleaners call a 72-hour strike; with } \\
\text { "largest duster" }\end{array}$ \\
\hline $07-02$ & The Hague & Protest on Plein Square & 200 & $\begin{array}{l}\text { To promote demands and protest against rise in } \\
\text { retirement age }\end{array}$ \\
\hline $10-02$ & Amsterdam & $\begin{array}{l}\text { Visit to "Zuidas" financial district and to VU } \\
\text { University }\end{array}$ & 300 & To promote demands \\
\hline $12-02$ & Utrecht & Meeting of cleaners at academic hospital & 30 & Lecture on "organizing” \\
\hline $15-02$ & Rotterdam & Demonstrations at several client companies & 150 & To promote demands \\
\hline $16-02$ & Groningen & Protest at railway station & 600 & $\begin{array}{l}\text { Official strike called by FNV Bondgenoten (Mari } \\
\text { Martens), starting } 4 \mathrm{pm}\end{array}$ \\
\hline $20-02$ & The Hague & Protest on Plein Square & 30 & To promote cleaners' demands \\
\hline $22-02$ & Groningen/Zwolle & Travelling by train & 40 & $\begin{array}{l}\text { Striking train cleaners from Groningen go to Zwolle } \\
\text { Station to assist strikers }\end{array}$ \\
\hline $22-02$ & Eindhoven & Demonstration by train cleaners at railway station & 60 & $\begin{array}{l}\text { Warming up for protest in Utrecht on 23-02; again } \\
\text { with "largest duster" }\end{array}$ \\
\hline $22-02$ & Maastricht & Demonstration by train cleaners at railway station & 60 & Ditto \\
\hline
\end{tabular}




\begin{tabular}{|c|c|c|c|c|}
\hline Date & Place & Type of action & $\begin{array}{l}\text { Estimated no. of } \\
\text { participants }\end{array}$ & Details \\
\hline $23-02$ & Utrecht & Demonstration/protest at Jaarbeurs Square & 600 & At the headquarters of Nedtrain \\
\hline $25-02$ & Utrecht (?) & Meeting / video shoot & 400 & Support for striking cleaners at Minnesota Airport \\
\hline $25-02$ & Enschede & Picket & 25 & $\begin{array}{l}\text { Striking train cleaners from Groningen, Zwolle, and } \\
\text { Enschede }\end{array}$ \\
\hline $25-02$ & Utrecht & Meeting & 200 & $\begin{array}{l}\text { Meeting of strike leaders from different locations } \\
\text { reporting on the strike }\end{array}$ \\
\hline $26-02$ & The Hague & Protest at Plein Square & 200 & To promote demands \\
\hline $05-03$ & Almelo & Visit to headquarters of Asito cleaning company & 200 & To promote demands \\
\hline $08-03$ & Heerlen & Visit to office of Hago cleaning company & 250 & $\begin{array}{l}\text { Bringing coal to symbolize the old-fashioned labour } \\
\text { relations }\end{array}$ \\
\hline $09-03$ & Schiphol Airport & Protest & 1,000 & To show perseverance \\
\hline $16-03$ & Utrecht & Sit-in strike and sleep-in at Utrecht Central Station & 300 & Start of sleep-in at $4 \mathrm{pm}$ \\
\hline $18-03$ & Utrecht & Sit-in strike and sleep-in at Utrecht Central Station & 300 & End of sleep-in \\
\hline $20-03$ & Utrecht & "Family day" & & \\
\hline $22-03$ & Utrecht & Visit to the NS railway company at Central Station & 25 & $\begin{array}{l}\text { NS director receives "the gold currant award" (in } \\
\text { Dutch, the word krent [currant] also means a close- } \\
\text { fisted frugal person) }\end{array}$ \\
\hline $24-03$ & Amsterdam & Meeting at Westergasfabriek, Amsterdam & 800 & $\begin{array}{l}\text { Decision to continue the strike after failed } \\
\text { negotiations }\end{array}$ \\
\hline $30-03$ & Amsterdam & Protest at UWV (social insurance board) & 200 & To promote demands \\
\hline $08-04$ & The Hague & Visit to the Royal Palace & & \\
\hline $13-04$ & Uden & $\begin{array}{l}\text { Occupation of headquarters of CSU cleaning } \\
\text { company }\end{array}$ & 500 & Ditto \\
\hline $22-04$ & Bunnik & Party to celebrate the end of the strike & 1,000 & Singing and dancing to celebrate success \\
\hline
\end{tabular}

Sources: http://mediabank.fnv.nl/; YouTube video clips; newspaper clippings Ron Meyer; Heuts, Tegenmacht. 